Publisher: TAYLOR \& FRANCIS INC, 325 CHESTNUT ST, SUITE 800, PHILADELPHIA, PA 19106 USA

Subject Category: Food Science \& Technology; Nutrition \& Dietetics

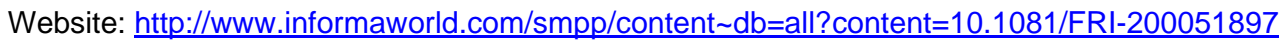

ISSN: 8755-9129

\title{
Analytical Methods in Wineries: Is It Time to Change?
}

\author{
M. D. LUQUE DE CASTRO, ${ }^{1}$ J. GONZÁLEZ-RODRÍGUEZ, ${ }^{2}$ \\ AND P. PÉREZ-JUAN ${ }^{3}$ \\ ${ }^{1}$ Department of Analytical Chemistry, Campus of Rabanales, Córdoba, Spain \\ ${ }^{2}$ Southampton Oceanography Centre, George Deacon Division, Waterfront \\ Campus, European Way, Southampton, United Kingdom \\ ${ }^{3}$ LIEC, Polígono Industrial, Manzaranes Ciudad Real, Spain
}

A review of the methods for the most common parameters determined in wine-namely, ethanol, sulfur dioxide, reducing sugars, polyphenols, organic acids, total and volatile acidity, iron, soluble solids, $\mathrm{pH}$, and color-reported in the last 10 years is presented here. The definition of the given parameter, official and usual methods in wineries appear at the beginning of each section, followed by the methods reported in the last decade divided into discontinuous and continuous methods, the latter also are grouped in nonchromatographic and chromatographic methods because of the typical characteristics of each subgroup. A critical comparison between continuous and discontinuous methods for the given parameter ends each section. Tables summarizing the features of the methods and a conclusions section may help users to select the most appropriate method and also to know the state-of-the-art of analytical methods in this area.

Keywords Parameters, Official methods, Usual methods, Non chromatographic methods, Chromatographic methods

Wine is a product with a very complex composition. Among the large number of substances found in wine, many are at very low concentrations even though they play a main role in wine characteristics, evolution, and/or quality. A complete analysis of wine is a time-consuming process, but it yields the necessary information for both elaboration of a quality product and conservation under proper conditions. Usually, the number of parameters to be analyzed is simplified as a function of the aim, the commonest being either to know the evolution of the process or to fulfill food laws. The more detailed the analysis is, the better knowledge of the wine is achieved, but a compromise between time and information requirements must be established in order to guarantee a given quality with minimum cost. Therefore, only a few parameters are periodically checked. Between them, the most common are: soluble solids, reducing sugars, alcoholic degree, $\mathrm{pH}$, total and volatile acidity, sulfur dioxide, color, polyphenol index, iron, and organic acids. 
Most analytical methods for monitoring wine composition recognized by the international community as official methods of analysis are manual methods with high robustness and precision, even though more recent methods may be based on modern automated instrumental techniques. Nevertheless, the manual methods are slow, tedious, and require a high level of human participation. Thus, their application is a balance between the number of parameters required for monitoring wine production, frequency of analysis, and cost of human and material resources. The new faster methods, which usually have the appropriate sensitivity, selectivity, and precision, can circumvent the problem created by the large number of samples to be analyzed in order to guarantee proper monitoring of wine production.

In the last 10 years, rapid and high sample throughput methods of analysis have been developed. It is interesting to know the features of these new methods-mainly in terms of accuracy and precision-for their potential application in enological laboratories. The possibility of automating methods commonly used in enological laboratories or applying new methodologies in routine tasks is shown in the "International Collection of analysis methods for wines and musts" edited by the "Office International de la Vigne et du Vin (OIV)" (1990). Official implementation of these methods makes mandatory a previous exhaustive comparison with the International Official Methods of Analysis in order to demonstrate the accuracy of the determinations and traceability of the data obtained. The OIV protocol (Resolution OENO 6/2000) enables evaluation of the requirements an analytical method must accomplish for validation.

This review is aimed at showing the methods published in the last 10 years and comparing their more outstanding analytical features with those of the official or reference methods established by the Office Internationale de la Vigne et du Vin (OIV). The authors try to fill a gap in this field of applied analytical chemistry as there are no recent reviews about the advances in analytical methods for determining the most typical enological parameters as done for traditional methods in the books from Ribereau-Gayon (1958) or Amerine and Ough (1976) and the compilation of the different official national and international regulations (EEC, 1989). Some previous reviews within the last ten years have been devoted to groups of analytes (Wagner et al., 1992a; Mateo and Jiménez, 2000; Vereda-Alonso et al., 2000; Scollary, 1997; Rapp and Versini, 1996) or techniques involved in the methods (Luque de Castro and Luque-Garcia, 2000; Cserhati et al., 2000; Navas and Jiménez, 1999; Wagner et al., 1992b; Baluja-Santos and González-Portal, 1992; Dell'Oro, 1991). They have not given an overall scope of the state-of-the-art of analytical methods in this field. To outline the potential application of new continuous and discontinuous analytical methods in enology, they have first been grouped as a function of the analyte to be determined and then on whether they can be used in batch or continuous analysis.

\section{Determination of the Alcoholic Degree}

Alcoholic degree is defined as the number of liters of ethanol contained in a hundred liters of wine. Most methods, both official or not, require a previous distillation step (simple or by steam dragging). Alcoholic degree traditionally has been determined in the distillate either by picnometry, which is the international official method-the repeatability and reproducibility of this method are 0.1 and $0.19 \%(\mathrm{v} / \mathrm{v})$, respectively (OIV, 1990, p. 61); areometry, with a repeatability of $\pm 0.1 \%$ II (v/v) (Ribereau and 
Peinaud, 1958); by chemical oxidation, with a precision of $\pm 0.04-0.07 \%(\mathrm{v} / \mathrm{v})$ (Amerine and Ough, 1976a); refractometry, with an error in measurement smaller than $2 \times 10-5 \mathrm{~g}$ $\mathrm{mL}-1$ (Amerine and Ough, 1976b); by using a hydrostatic scale (Amerine and Ough, 1976b); enzymatically, which yields a precision of $\pm 0.6 \%$ (Amerine and Ough, 1976c); or by gas chromatography, with a precision of $0.2 \%$ (Amerine and Ough, 1976c). The method based on observation of the decrease in boiling point has a precision of $0.2 \%$ $(\mathrm{v} / \mathrm{v})($ Amerine and Ough, 1976d), and uses nondistilled wine.

\section{Discontinuous Methods}

Some of the most outstanding discontinuous methods developed in the last 10 years are summarized in Table 1. They are mainly based either on sensors, both chemical and biochemical on derivatization reactions, or use of instrumental techniques.

Chemical sensors allow in situ monitoring of the analyte. They are simple devices with a fast response based generally on amperometry, so they do not require prior analyte derivatization (Tarnowski and Korzenieski, 1996; Promsong and Sriyudthsak, 1995). They can also use optical transduction involving an optode membrane and derivatizing reagents such as trifluoroacetophenone (Seiler et al., 1991) or fluorescein derivatives (Zeng et al., 1994), thus providing wide linear calibration ranges. Amperometry is the most common transduction technique for biosensors used for the determination of ethanol in wines. The biocatalyst immobilized in the active zone is either a dehydrogenase (Katriik et al., 1998; García-Mullor et al., 1996; García-Lobo et al., 1996; Boujita et al., 1996; Wang and Nasser, 1995; Rueger et al., 1991; Zhao and Buck, 1991; Zhou et al., 1993) or oxidase (Rueger et al., 1991). Sometimes, the nonisolate biocatalyst is used, as is the case with the whole aerobic bacterium (Wang et al., 1997). Most times, these biosensors do not require sample pretreatment because the biocatalysis is selective enough. The sensitivity provided by biosensors allows establishing linear ranges of concentration from $10-6$ up to $0.1 \%(\mathrm{v} / \mathrm{v})$ using sample dilution as the only pretreatment. Dilution of the sample avoids biocatalyst inhibition and enlarges the biosensor lifetime, but dilution is also the main source of error. The average precision of these methods is less than $2 \%$ of relative standard deviation (RSD), but they are not accurate enough to meet the legal requirements. In addition, the nature of the matrix in fermentation processes, rich in proteases, can denature the immobilized biocatalyst, thus making biosensor-based methods useless for monitoring these processes.

Most chemical methods for the determination of ethanol are based on visible (Sasaki et al., 1993; Magri et al., 1997; Dai et al., 1996; Zhang, 1990) or infrared (Garcia-Jares and Medina, 1997; Luo and Liu, 1998) spectroscopy as detection techniques. The most usual method is based on the classical reaction with potassium dichromate and monitoring of the $\mathrm{Cr}+3$ formed (Magri et al., 1997). In other methods, the monitored species is the reaction product between the distillate and potassium ethyl ester (Zang et al., 1990), nickel bis (oo'-dipropyldithiophosphate) (Sasaki et al., 1993) or eosin (Dai et al., 1996). These methods are expensive, time-consuming and have low sample throughput. The average precision is similar to that obtained by the previous-mentioned methods and ranges between $0.8 \%$ and $4 \%$ in terms of RSD.

Methods for determining alcoholic degree in wine have also been based on nuclear magnetic resonance (NMR) detection (Barjat et al., 1993; Belton and Gadsby, 1992), which needs no previous treatment steps nor derivatization. Calibration curves are based 
on the triplet of the methyl group, with linear range from $0.01 \%$ to $15 \%$ of ethanol with absolute errors of $\pm 0.3 \%$. Simpler instrumentation than NMR detection is near-infrared spectroscopy (NIR) (Pérez-Ponce et al., 1996; Schindler et al., 1998), which requires only prior sample dilution. Linear ranges of these methods are suitable for winery requirements, but they are neither accurate nor precise enough (RSD from $0.3 \%$ to $6.5 \%$ ).

\section{Continuous Methods}

The most remarkable continuous methods for the determination of ethanol in wine are summarized in Table 2. These methods can be divided into chromatographic and nonchromatographic.

The former group involve HPLC or GC, whereas and the second are flow-injection methods based on chemical or biochemical derivatizing reactions either with or without a previous separation or clean-up step.

In GC methods, no derivatization or sample pretreatment is required and flame ionization detection (FID) is used in all instances (Anon, 1998; Ames et al., 1997; Wu, 1992; Yan et al., 1992). In order to increase sensitivity, the headspace technique is sometimes used (Yan et al., 1992). Methods based on liquid chromatography make mandatory a pretreatment step consisting of filtering, degassing, and diluting, and subsequent dialysis in some cases (Linget et al., 1998). The most common measurements are based on refractive index (Falque-López and Fernández-Gómez, 1996; Sánchez-Muñoz et al., 1992; Calull et al., 1992), and some times, near infrared spectroscopy with Fourier Transform (Linget et al., 1998). The average precision (as RSD) is over 5\%. In general, these methods are not accurate enough for legal requirements and they are useless in routine analysis with errors higher than $0.2 \%(\mathrm{v} / \mathrm{v})$, which is the maximum error permitted in trade analysis of wine.

Flow injection (FI) is a low-pressure, low-cost continuous technique, the versatility and availability of which enable the desired level of automation to be implemented in enological laboratories. In addition, in-line location of separation/preconcentration modules endows the methods thus developed with the appropriate degree of selectivity and sensitivity.

The precision of FI methods surpasses or equalizes that of their batch counterparts. The flow injection methods for determination of ethanol developed so far can be divided mainly into three types according to the derivatization step: enzymatic methods (Wangsa and Danielson, 1991; Kuennecke and Schmid, 1990; Mattos et al., 1995; Xie et al., 1992; Rangel and Toth, 2000) [using alcohol dehydrogenase (EC 1.1.1.1) or alcohol oxidase (EC 1.1.3.13)], redox methods based on oxidation of ethanol with dichromate in acid medium (Mattos et al., 1998; Polo et al., 1986; Mataix and Luque de Castro, 2000a), and those in which no derivatization is required (Chen et al., 1997; Mataix and Luque de Castro, 2000b; González-Rodríguez et al., 2003). In general, the separation techniques used, if necessary, are gas diffusion (Mattos et al., 1998; Polo et al., 1986; Mohns and Kuennecke, 1995; Kuennecke and Schmid, 1990) or pervaporation (Delgado-Reyes et al., 1998; Maitaix and Luque de Castro, 2000b; González-Rodríguez et al., 2003). The usual detection techniques are spectroscopic (photometry or fluorimetry) and electrochemical (amperometry or potentiometry). A number of methods in the literature compare their results with those from unofficial reference methods based on liquid or gas 
chromatography, and enzymatic and redox reactions, which do not offer accurate results. The FI methods, in general, do not yield accurate but precise results (RSD $0.1 \%-3.9 \%$ ). In general, nonenzymatic FI methods are more precise than are enzymatic ones. The main error sources of these methods are sample dilution and the lack of temperature control, which seriously affect the sample volume of alcoholic solutions. The error in most enzymatic methods is not high enough for rejection, and they are more suitable than are nonenzymatic methods for on-line monitoring because of the high sampling throughput. Some of the proposed FI methods (Mattos et al., 1995; Rangel and Toth, 2000; Mattos et al., 1998; Mataix and Luque de Castro, 2000a; González-Rodríguez et al., 2003) are accurate and precise enough to be used for the legal determination of ethanol content in wine.

\section{Discontinuous vs. Continuous Methods}

In comparing the characteristics of continuous and discontinuous methods, the accuracy and precision provided by the former are better than those of the latter. This can be due to low degree of human participation, insufficient pretreatment steps or nonequilibrium measurements, which minimize matrix effects. The nonequilibrium methods are also the fastest, and so, are suitable for on-line fermentation monitoring. A preset accuracy is not required in these processes and a high analysis frequency is one of the most valuable characteristics.

Many of the reviewed methods are compared with unofficial methods for validation. This involves a significant source of error.

\section{Determination of Sulfur Dioxide}

Most methods for determination of sulfur dioxide are based on oxidation into sulphuric acid. The OIV reference method is based on removing sulfur dioxide from wine by a nitrogen or air stream, subsequent oxidation with $\mathrm{H} 2 \mathrm{O} 2$ followed by titration of the sulphuric acid formed by a standard solution of sodium hydroxide (OIV, 1990, p.271). Differentiation between free and bound sulfur dioxide is achieved by changing the working temperature.

At $10^{\circ} \mathrm{C}$, only free sulfur dioxide is removed, whereas at $100^{\circ} \mathrm{C}$, both forms are removed. Repeatability and reproducibility depend on the content of sulfur dioxide in wine and typically range within $1-6 \mathrm{mg} 1-1$ and $9-15 \mathrm{mg} 1-1$, respectively. The widely used Ripper method (Amerine and Ough, 1976) consists of direct titration of sulfur dioxide by iodine using starch as the indicator. This method has two main shortcomings: the difficulty of proper distinction of the indicator change and the excess of iodine consumption due to reaction with the matrix. These problems yield positive errors, particularly in red wines, due to reagent consumption by polyphenols.

\section{Discontinuous Methods}

Discontinuous methods are scarce in the literature (Table 3), and are mainly based on electrochemical detection [namely, amperometry (Kawamura et al., 1994; Nakamura et al., 1993; Gomes et al., 1996), or voltammetry (Baldo et al., 1994; Cardwell et al., 1991) to quantify the analyte, although molecular (Edberg, 1993) or atomic (Sarudi and Kelemen, 1998) spectroscopy have also been used. 
The methods proposed so far are precise - average value of $3.8 \%$, expressed as RSD, and accurate enough for accomplishing the OIV requirements. Electrochemical methods enable individual determination of free and bound sulfur dioxide, but in the case of atomic methods the linear ranges are narrower than are required in order to analyze total sulphur dioxide. Therefore, a prior sample dilution is required in order to use them routinely for measurement of this overall parameter. The sample throughput is low (4-6 $\mathrm{h}-1)$.

\section{Continuous Methods}

The continuous methods in the literature for the determination of SO2 are also shown in Table 3. They involve sequential analysis of the two forms of the analyte by determining free $\mathrm{SO} 2$ directly, then determining total $\mathrm{SO} 2$, and obtaining the bound form by difference.

Sample pretreatment is only required for releasing bound SO2 and it consists of a basic hydrolysis. Gas diffusion (Azevedo et al., 1999; Silva et al., 1998; Kuban et al., 1998; Araujo et al., 1998; Su et al., 1998; Decnop-Weever and Kraak, 1997; Lin and Hobo, 1996; García-Prieto et al., 1994; Thanh et al., 1994; Huang et al., 1992; Bartroli et al., 1991; Mana and Spohn, 2001; Segundo and Rangel, 2001; Segundo et al., 2000; Cardwell and Christophersen, 2000; Atanassov et al., 2000) is the most common separation technique if removal of the analyte from the matrix is required. The use of this technique provides slightly higher average precision $(2.3 \%$ vs. 3.3\%) than do other separation techniques such as pervaporation (Mataix and Luque de Castro, 1999; Mataix and Luque de Castro, 1998), evaporation (Zhi et al., 1995), or ion exchange (Richter et al., 1993).

Derivatization of $\mathrm{SO}_{2}$ may be accomplished with a variety of reagents, the most common being that based on reaction with the p-rosaniline+formaldehyde mixture (Lin and Hobo, 1996; Mataix and Luque de Castro, 1999; Mataix and Luque de Castro, 1998; Richter et al., 1993). Biocatalyzed (Huang et al., 1992; Rezende and Mottola, 1994; Fatibello-Filho and da Cruz Vieira, 1997; Yao et al., 1994) or redox reactions using H2O2 (Su et al., 1998; Huang et al., 1992; Pérez-Ruiz et al., 1993) and I2 (Kuban et al., 1998; Lin and Hobo, 1996; Thanh et al., 1994) as oxidants are also used. Amperometric (Azevedo et al., 1999; Thanh et al., 1994; Rezenda and Mottola, 1994; Cardwell et al., 1993; Cardwell et al., 1991b) and photometric detectors (Kuban et al., 1998; Decnop-Weever and Kraak, 1997; García-Prieto et al., 1994; Bartoli et al., 1991; Segundo, 2000; Atanassov et al., 2000; Mataix and Luque de Castro, 1998; Zhi et al., 1995; Richter and Luque de Castro, 1993; Fatibello-Filho and de Cruz-Vieira, 1997, Pérez-Ruiz et al., 1993) have been widely used with similar frequency, providing similar accuracy and precision.

Less common is the use of potentiometric (Araujo et al., 1998; Mataix and Luque de Castro, 1999) and chemiluminescence detectors (Lin and Hobo, 1996; Huang, et al., 1992).

The linear range of most methods is lower than is the normal content of $\mathrm{SO}_{2}$ in wines, which makes mandatory dilution of the sample with the concomitant error. The results obtained by FI methods agree with those provided by the reference methods. The accuracy ranges between $90 \%-105 \%$. The FI methods involving a separation step are sometimes even more robust than reference methods as the nonequilibrium conditions for monitoring decrease the errors caused by the excess of iodine that the wine matrix 
consumes. The previous separation step usually increases the selectivity and sensitivity of the methods. High sampling frequencies $(5-120 \mathrm{~h}-1)$ and low detection limits $(0.05-1.2$ mg 1-1) with none or limited interferences are also common characteristics of these methods.

\section{Discontinuous vs. Continuous Methods}

Continuous methods are widely compared with discontinuous methods in the literature with the following general conclusions: the former provide higher sample throughput, higher precision and accuracy, lower detection limits, lower reagent consumption, and lack of interferences or matrix effects when previous separation of the analyte is performed.

In the last five years, all the methods in the analytical literature for the determination of sulfur dioxide in wines are based on flow injection. This fact points out one of the present trends in this area.

\section{Determination of Reducing Sugars}

Traditional methods for measurement of reducing sugars are based on reduction of $\mathrm{Cu}+2$ by carbonyl groups in boiling alkaline medium (Fehling, Ribereau-Gayon and Peinaud, 1958, p. 222; Bertrand, Ribereau-Gayon and Peinaud, 1958, p. 227; Rebelein, RibereauGayon and Peinaud, 1958, p. 228), Luf-Schoorl, Matissek et al., 1992) and the official method of the OIV (OIV, 1990). In order to avoid interferences due to polyphenols, prior precipitation is recommended using zinc ferricyanide or lead acetate. An acid hydrolysis of sucrose is mandatory in order to obtain glucose and fructose. The OIV (OIV, 1990) values for repeatability and reproducibility of the assays depend on the sugar content and they are $0.015 x$ and $0.058 x$, respectively ( $x$ is concentration of inverted sugar in $\mathrm{g} 1-1$ ).

\section{Discontinuous Methods}

There are only a few discontinuous methods in the literature for determining reducing sugars in wine. Some amperometric biosensors have been proposed for the determination of glucose and fructose using either glucose oxidase (Svorc et al., 1997; Bilitewski et al., 1992; Miertus et al., 1998) or glucose dehydrogenase (Miertus et al., 1998; Stredansky et al.,1999) for the former and fructose dehydrogenase for the latter. The isolated enzymes are immobilized on different supports (membranes or other materials). These methods are precise enough $(\mathrm{RSD}=1.8 \%-2.1 \%$ ) for winery requirements and they need only prior sample dilution. The average lifetime of these biosensors is one month. The main problem of these methods is the inhibition of the enzymes owing to wine components. Sample dilution can, sometimes, overcome this problem.

Other methods use potentiometry (Nanos and Karayannis, 1991) — with tedious sample pretreatment - or NIR (García-Jares and Medina, 1997) and Fourier transform infrared (FTIR) (Anderson et al., 2002) as detection techniques. The former require previous chemometric calibration using a validation set of samples with known concentrations, and the precision $(\mathrm{RSD}=5.3 \%)$ is not as good as that of the other methods. The advantage of the methods based on NIR is their ability for multidetermination, which compensates the time required for calibration.

NMR has been rarely used for sugar quantification (Barjat et al., 1993). Nevertheless, this technique is useful both for the detection of illegal sugar addition before wine 
fermentation (Kosir et al., 2000; Fauhl and Wittkowski, 1996) and differentiation of wines according to their geographical origin (Kosir et al., 2000). The instrumentation is expensive, for both acquisition and maintenance, and needs skilled personnel to run it.

\section{Continuous Methods}

Continuous methods can be divided into chromatographic and nonchromatographic. There are some references in the literature concerning the determination of reducing sugars by chromatographic methods in which sample treatment, if required, consists of filtering or dilution. High pressure liquid chromatography (HPLC) is the most common technique with (Lodi et al., 1994; Coquet et al., 1994; Murakami et al., 1991; Murakami et al., 1996) or without (Linget et al., 1998; Wang et al., 1992; Kaufmann, 1993; Vonach et al., 1998; Zhu et al., 1997c) post-column derivatization making use of glucose oxidase immobilized in a reactor (Murakami et al., 1991) or on the surface of an electrode (Murakami et al., 1996). Methods based on photometric (Kaufmann, 1993), FTIR (Vonach et al., 1998), fluorimetric (Lodi et al., 1994; Coquet et al., 1994), refractive index (Linget et al., 1998; Wang et al., 1992; Kaufmann, 1993) and amperometric (Murakami et al., 1991; Murakami et al., 1996; Zhu et al., 1997; Casella et al., 1998) detection have also been reported. In general, low detection limits and good precision (average values smaller than 3\% in terms of RSD) have been obtained for continuous methods. Linear ranges of these methods make them suitable for most wine types, with or without previous dilution.

Despite the fact that no separation step is needed, dialysis is sometimes used (Appelqvist and Hansen, 1999) in flow infection (FI) methods. The derivatization step is based on a redox reaction, mainly with a copper salt (Yerba et al., 1993; Araujo et al., 2000; PerisTortajada et al., 1992), or using immobilized enzymes [such as glucose oxidase (Yokoi et al., 1995; Matsumoto et al., 1991; Schuhmann, 1991), glucose dehydrogenase (Appelqvist and Hansen, 1999) or mannitol dehydrogenase (Kiba et al., 1991)] packed in a reactor. Photometric detection of the reaction products is mainly used (Araujo et al., 2000; Peris-Tortajada et al., 1992; Yokoi et al., 1995; Hsieh and Crouch, 1993; Hartmann et al., 1994; Oliveira and Fatibello-Filho, 1999), but other alternatives such as amperometry (Appelqvist and Hansen, 1999; Matsumoto et al., 1991; Kiba et al., 1991), fluorimetry (Schuhmann, 1991), or atomic spectroscopy (Lopes et al., 1995) have also been used.

Average errors of these methods are about $7 \%$ and all them present good precision $(\mathrm{RSD}=0.4 \%-3.9 \%)$. However, the lack of a previous precipitation step can yield error by excess in red and dry wines. The results obtained by FI methods agree with those obtained by using enzymatic batch methods. Flow injection methods use the catalyst immobilized on an appropriate support, which have the following advantages: low cost per analysis due to reuse of the biocatalyst, high sample throughput $(50 \mathrm{~h}-1)$, and low detection limits $(0.05 \mathrm{~g} 1-1)$.

\section{Discontinuous vs. Continuous Methods}

The most recent discontinuous methods for reducing sugars do not have advantages when compared with continuous methods. The use of NMR can be justified in order to detect illegal sugar additions and differentiation of wines according to geographical origin. In general, all the analytical features of the continuous methods found in the literature are 
better than are those of the discontinuous ones. The advantage of using chromatographic methods is multidetermination. Most HPLC sugar methods in the literature also involve the determination of organic acids.

\section{Determination of Organic Acids}

The organic acids usually determined in enological laboratories are malic, lactic, tartaric, and gluconic acids (Flanzy, 2000); and their monitoring is related to wine technological processes or quality aspects.

The OIV reference method for the determination of L-malic acid in wines is based on oxidation of malic acid to oxaloacetate under L-malate dehydrogenase catalysis using (nicotinamide-adenosine dinucleotide (NAD) as coenzyme. The concentration of the reduced form of the coenzyme (NADH) formed is photometrically monitored at $340 \mathrm{~nm}$ (OIV, 1990, p.195). Prior dilution of the sample is required when L-malic is over $350 \mathrm{mg}$ $1-1$. The repeatability and reproducibility of these assays depend on the L-malic acid content and they are $0.03+0.034 \mathrm{x}$ and $0.05+0.071 \mathrm{x}$, respectively ( $\mathrm{x}$ is concentration of L-malic in the sample in g 1-1). The reference method for lactic acid (OIV, 1990, p.179) is also based on an enzymatic reaction by which the analyte is oxidized to piruvate by lactate dehydrogenase with photometric monitoring of the NADH formed. The repeatability $(r)$ and reproducibility $(R)$ depend on the lactic acid concentration, $r=0.02$ $+0.07 \mathrm{x}$ and $\mathrm{R}=0.05+0.125 \mathrm{x}(\mathrm{x}=$ lactic acid concentration in $\mathrm{g} 1-1)$. Prior dilution is also required when L-lactic acid is over $100 \mathrm{mg} 1-1$. The reference method for the determination of tartaric acid (OIV, 1990, p.169) consists of the gravimetric determination of tartaric acid after precipitation as racemic calcium tartrate.

Finally, there is no official method used to determine gluconic acid in wine. The most usual method uses commercial enzymatic kits (Boehringer Mannherm Cat No 428191) for the reaction of the analyte with gluconate kinase and adenosine-5'-triphosphate and subsequent reaction of the product and the oxidized form of nicotinamide-adenine dinucleotide phosphate (NADP+) catalyzed with 6-phosphogluconate dehydrogenase to yield ribulose-5-P and NADPH. The increase of NADPH is photometrically monitored.

\section{Discontinuous Methods}

In the literature there are some discontinuous methods for determining organic acids, both for single and multidetermination. Of the former, the most important are those based on enzymatic reactions. So, L-malic acid can be determined by L-malate dehydrogenase catalysis with either spectrophotometric (Suye et al., 1992) or amperometric (Gillis and Comtat, 1995) detection; meanwhile, the determination of L-tartaric acid is based on the secondary activity of D-malate dehydrogenase and photometric detection (Tsukantani and Matsumoto, 1999). In general, average recoveries are between $98 \%-103 \%$, with RSD values close to $2 \%$. There are no discontinuous methods in the literature for the determination of gluconic acid in wine that are different from that based on the commercial enzymatic kit.

The discontinuous multidetermination methods for organic acids are exclusively based on FTIR (Patz et al., 1998; Schindler et al., 1998). These methods can determine most of the common organic acids. Other advantages of these methods include high degree of automation, high sample throughput (20-30 h-1), simple sample preparation, and low analysis costs; but the disadvantages include high instrument cost and the need for 
precise, updated, and product specific calibrations. In general, these methods are preciseenough, but the accuracy is not appropriate without previous calibration with a high number of samples.

\section{Continuous Methods}

Continuous methods for the determination of organic acids are the most common in the literature. They can be divided into nonchromatographic and chromatographic methods. The former provide single determinations-based on flow injection (FI) analysis - and the latter, multidetermination. Table 5 shows the FI methods for the determination of lactic, malic, and tartaric acids reported in the last 10 years. The majority of these methods are based on the use of enzymes both in solution and immobilized in a reactor and monitoring of the reaction products by photometric (Rangel and Toth, 1998; Garcia-deMaria et al., 1991; Mataix and Luque de Castro, 2001; Lima et al., 1998; Mallet et al., 1999), fluorimetric (Mataix and Luque de Castro, 2001; Puchades et al., 1991; Kiba et al., 1993), and chemiluminescence (Kiba et al., 1995; Hemmi et al., 1995) detectors. The biocatalyst can also be immobilized on the surface of a potentiometric (Sales et al., 2001; Ukeda et al., 1995) or amperometric (Serra et al., 1999; Yoshioka et al., 1992; Palleschi et al., 1994) electrode. No sample pretreatment other than dilution is usually required, and when a separation step is required, it consists of dialysis. The linear ranges are, in general, lower than are the usual values found in wines; therefore, prior sample dilution is usually required.

The detection limits are much smaller than are the usual values found in wines for all the studied organic acids and, in general, high sample throughput is obtained (15-80 $\mathrm{h}-1)$. Average precisions, in terms of RSD, are about 3.6\% for lactic and tartaric acids and $2.8 \%$ for malic acid. Average accuracies are between $92 \%-102 \%$ in most cases.

Chromatographic methods for the determination of organic acids are mainly based on HPLC (Guan et al., 1993; Billingsley et al., 1996; Zerbinati et al., 1994; Escobal et al., 1998; Escobal et al., 1997; Radin et al., 1994; Kaufmann, 1993; Chen and Hu, 1993; Calull et al., 1992; Vonach et al., 1998; Bi and Gu, 2000; Jun and Lima, 1996; Wang et al., 1993), but some methods based on gas chromatography (GC) (Hu and Li, 1993) and ion chromatography (IC) (Mou et al., 1992; Gao and Fu, 1994; Yu et al., 1993) have been developed. Capillary electrophoresis (CE) (Castineira et al., 2000) methods are also included in this section.

Most of these methods enable multidetermination, but also single determinations of malic (lgler and Rauter, 1996) or lactic (Feng and Zhou, 1992) acids can be found in the literature by using GC prior to analyte derivatization, which consists of methylation or treatment with $\mathrm{HClO} 4$. Precisions between $1.8 \%-7 \%$ and accuracy values between $90 \%-$ $100 \%$ are obtained. Tartaric acid is also determined by using CE (Mallet et al., 1999) with precision over $4 \%$ and accuracies ranging between $100 \%-103 \%$.

Table 6 shows some of the most notable continuous methods for the multi-determination of organic acids. HPLC methods are the most numerous, with no or very simple pretreatment steps, without derivatization reactions, and use of photometric detectors (Guan et al., 1993; Billingsley et al., 1996; Zerbinati et al., 1994; Escobal et al., 1998; Escobal et al., 1994; Radin et al., 1994; Kaufmann, 1993; Chen and Hu, 1993), although 
detectors based in refractive index measurements (Calull et al., 1992) and FTIR (Vonach et al., 1996) are also used to yield overall average precision of about $3.7 \%$ in terms of RSD, and accuracy ranging between $90 \%-106 \%$. Use of HPLC even allows the determination of organic acid enantiomers (Buglass and Lee, 2000) in diluted wine and codetermination of reducing sugars, ethanol, and glycerol (Kaufmann, 1993). A GC method $(\mathrm{Hu}$ and $\mathrm{Li}, 1993)$ is based on derivatization of the organic acids into volatile esters with flame ionization detection and recoveries between $96 \%-105 \%$, but without sufficient enough precision ( $\mathrm{RSD}=1.1 \%-14.5 \%$ ) even through accuracy is acceptable. Methods based on ion chromatography (Gao and $\mathrm{Fu}, 1994$; $\mathrm{Yu}$ et al., 1995) require previous sample dilution, but not derivatization. These methods show good precision, $\mathrm{RSD}=1.4 \%$, and average accuracy values between $94 \%-103 \%$.

Other alternatives for multidetermination of organic acids use capillary electrophoresis (Castineira et al., 2000) with no previous derivatization and photometric detection, and give good precision $(\mathrm{RSD}=1 \%$ ) and recovery ranging between $90 \%-102 \%$.

\section{Discontinuous vs. Continuous Methods}

A number of advantages of continuous methods when compared with discontinuous methods can be found. Single parameter determination using continuous methods are endowed with high sample throughput and low maintenance or reagents cost. This aspect makes them suitable for on-line determinations in evolving processes, for which the accuracy and precision of these methods are good enough. They are based on FI and, because of their modular design, the experimental setup can be located either at-line or on-line in industrial plants to monitor processes such as malolactic fermentation. Single determinations based on discontinuous methods are accurate and precise but tedious and have low sample frequency, so their use is limited.

One promising alternative to continuous methods are methods based on FTIR, which are discontinuous methods but easy to automate and with high sample throughput. They are precise and allow organic acid multidetermination that yields additional information about ethanol, reducing sugars content, and other enological parameters such as $\mathrm{pH}$ and volatile and total acidity. These methods need specific calibration with a large number of samples of previously determined concentrations. The wide ranges of wine components seriously affect the determination of these parameters, thus making long and tedious single calibrations for each kind of wine mandatory. These methods are accurate enough when these requirements are accomplished, and periodical updated calibration is carried out. Nowadays, these methods are used for screening and monitoring processes when a high accuracy is not required.

When high accuracy and/or precision are required, at present HPLC methods are the best option. The chromatographic separation avoids matrix effects and offers the possibility for organic acids multidetermination and additional determinations of reducing sugars and ethanol, thus making them suitable for quality control. The disadvantages of these methods are low sample throughput and high maintenance costs, shortcomings that are compensated by the amount of information each analysis provides.

\section{Determination of Titratable and Volatile Acidity}


Total or titratable acidity is the sum of all acids present in wine expressed as $g$ of tartaric acid 1-1. The official method consists of titration with $\mathrm{NaOH}$ up to $\mathrm{pH} 7.0$ (OIV, 1990, p.155) or 8.2 (AOAC, 1970, p.144) depending on whether the OIV or AOAC criterium is followed, respectively. The OIV official method is based on potentiometric or colorimetric titration of total acids in wine, and the repeatability is $0.07 \mathrm{~g}$ of tartaric acid 1-1 for both white and red wines, with, reproducibility \& either $0.3 \mathrm{~g}$ of tartaric acid 1-1 or $0.4 \mathrm{~g}$ of tartaric acid 1-1 for both white and red wines, respectively.

Volatile acidity is due to organic acids such as formic, acetic, or butyric acids. Traditional methods are based on wine distillation, with (Ribereau-Gayon et al., 1976, p.256) or without (Ribereau-Gayon et al., 1976, p.254) addition of water or on extraction with water vapor (OIV, 1990, p.159). The official method of analysis is based on the latter separation step. In all cases, subsequent titration with $\mathrm{NaOH}$ and correction for avoiding the contribution from SO2 or sorbic acid are made. The repeatability and reproducibility of the official method are $0.04 \mathrm{~g}$ of acetic acid $1-1$ and $0.08 \mathrm{~g}$ of acetic acid 1-1, respectively.

\section{Discontinuous Methods}

There is in the literature only a recent discontinuous method for the determination of volatile acidity (Garcia-Jares and Medina, 1995) however, there are some methods for the determination of total or titratable acidity. The method to determine volatile acidity also allows the determination of the total acidity, and it consists of a partial least squares model that relates UV/visible wine spectra with these two parameters. Conventional methods for the determination of total acidity are simple, and are based on the usual principle to determine total acidity, with either voltammetric (Ohtsuki et al., 2001; Baldo et al., 1998) or potentiometric (Cardwel et al., 1992) detection. These methods do not require a previous sample treatment nor separation, but they do not offer advantages, with respect to the existing methods, in accuracy, precision, or sample throughput.

\section{Continuous Methods}

There are in the literature six continuous methods, all based on FI, for the determination of one or the two of the parameters in a sequential way; three of them involve a separation step, which is not required in the other three. The technique used for analyte separation in the case for volatile acidity has been gas diffusion (Barros and Turbino, 1992) or analytical pervaporation (Mataix and Luque de Castro, 1999; GonzálezRodriguez et al., 2001) with subsequent photometric or conductimetric detection. One of them, which is based on flow injection-pervaporation (Mataix and Luque deCastro, 1999) enables the sequential determination of the total and volatile acidity. These methods are precise (RSD $<5 \%$ ) and accurate enough (error $<4 \%$ ) for accomplishing the OIV requirements for validation.

They are also endowed with high sample throughput $(10-60 \mathrm{~h}-1)$ and capability for automation, thus making them suitable for winery requirements. Continuous methods for determination of total acidity in wines (Mataix and Luque de Castro, 1999; Gaiao et al., 1999; Rangel and Toth, 1998) without separation steps use photometric detection and acid-base colored indicators. These methods are simple, fast, accurate, and precise enough (average RSD $<5 \%$ ) to accomplish OIV requirements. Only previous debubbling 
is required in order to remove carbonic acid from wine, which is not included in total acidity.

\section{Discontinuous vs. Continuous Methods}

All continuous methods are based on flow injection and endowed with the characteristics of this technique, thus allowing an advantageous comparison with discontinuous methods. The latter only are useful in the case of multidetermination, as in the method proposed by García-Jares and Medina (1995), which enables determination of $\mathrm{pH}$, free $\mathrm{SO} 2$, tannins, and total anthocyans. The continuous method developed by Mataix and Luque de Castro (1999) enables the sequential determination of total and volatile acidity. Among the methods for detecting volatile acidity, the most accurate results are obtained by those involving separation steps, as matrix effects are thus avoided.

\section{Determination of Iron}

Atomic absorption spectrometry (AAS) is the technique used for the official determination of iron in wine (OIV, 1990, p. 221) along with the previous steps of wine dilution, if required, and removal of ethanol. The most usual method for iron analysis in wineries is based on molecular absorption after complex formation with orthophenanthroline (OIV, 1990, p.222) or thyocianate (Amerine and Ough, 1976) and photometric monitoring at $508 \mathrm{~nm}$.

\section{Discontinuous Methods}

Atomic absorption spectrometry has been widely proposed for the determination of iron (Subecic et al., 1998; Chmilenko and Baklanova, 1997; Escobal et al., 1995; Olalla et al., 2000) after a mineralization step in order to obtain the total content of iron in wine. These methods are accurate (average accuracy range between $98 \%-101 \%$ ), selective, with high precision (RSD $<2 \%$ ), and have low detection limits. A simple and cheap alternative to AAS is photometric detection after a derivatization reaction, which can consist of forming a complex with thyocianate ( $\mathrm{Ga}$ and Liu, 1996), triazine (Toral and Almendrades, 1991) or phenanthroline (Capitán-Garia et al., 1995) or even using optical sensors (Capitán-Vallvey et al., 2001). These methods show high reproducibility, low detection limits (about $40 \mu \mathrm{g}^{-1}$ ), high selectivity, and precision below $2 \%$ in terms of RSD. Iron can also be determined by electroanalytical techniques such as polarography (Vázquez-Díaz et al., 1994) and stripping voltammetry (Miao, 1993) or by fluorimetric methods with prior derivatization with fluorescent reagents (Fang and Zhang, 1993; Wu et al., 1999; Mannino and Brambilla, 1992; Zeng and Jewsbury, 2000), with average precision $<1.5 \%$, expressed as RSD, and accuracy values below $5 \%$.

\section{Continuous Methods}

There are few continuous methods in the literature to determine iron, most them with based on flow injection using derivatization reactions with thyocianate (GonzálezRodríguez et al., 2002), phenanthroline (Neira et al., 2000), or hydroxylamine (Cladera et al., 1991) and photometric detection or derivatization with pioverdin (Pulido-Tofino et al., 2000) with fluorimetric detection. On-line determination of $\mathrm{Fe}+3$ and total iron (de Campos-Costa and Araujo, 2001) can be performed by using thyocianate and photometric 
determination for the former and AAS for the latter. The FI methods are precise (RSD < $4 \%)$ and fast $\left(20-30 \mathrm{~h}^{-1}\right)$.

\section{Discontinuous vs. Continuous Methods}

In this case, as for total and volatile acidity, all continuous methods based on flow injection allow an advantageous comparison with discontinuous methods. Derivatization prior to photometric detection is usually performed in all methods found in the literature, both continuous and discontinuous, rather than AAS detection, with similar values of accuracy and precision.

\section{Total Polyphenols}

Total polyphenols content in wines involves all compounds with a phenolic structure, described either by an adimensional index or by making a relationship with a standard compound, usually gallic acid. Most of these methods are based on the reducing properties of these compounds using potassium permanganate (permanganate index) (Ribereau-Gayon et al., 1976, p. 272) mixtures of phosphomolibdic and phosphotungstic acids (Folin-Ciocalteau) (OIV, 1990 p. 269) or iron (II) (Jerumanis index) (RibereauGayon et al., 1976, p. 274) as oxidizing reagents. Folin-Ciocalteau is the OIV reference method and it is used in the European union EU as the official method of analysis with repeatability values smaller than 1 , expressed as RSD. The absorbance measurement at $280 \mathrm{~nm}$ (t.p.i.) is also used as a simpler but less sensitive method (Ribereau-Gayon et al., 2000).

\section{Discontinuous Methods}

Discontinuous methods for the determination of polyphenols in wines are mainly based on FTIR for analyte multidetermination (Patz et al, 1999), which present the same advantages and shortcomings described in the determination of organic acids. The method based on the use of a horseradish peroxidase biosensor (Imabayashi et al., 2001) for catalyzing the oxidation of polyphenols by $\mathrm{H} 2 \mathrm{O} 2$ has several advantages over the Folin-Ciocalteau method; namely; there is shorter analysis time, smaller sample volume, and greater tolerance to interfering substances. The use of cyclic voltammetry (Kilmartin et al., 2001) to characterize antioxidants, phenolics included, has also been proposed.

\section{Continuous Methods}

Flow injection methods for the determination of the total polyphenol index in wine are based on either measurement of the absorbance at $280 \mathrm{~nm}$ (Mataix and Luque de Castro, 2001; González-Rodríguez et al., 2002) or the use of the Folin-Ciocalteau reagent (Celeste et al., 1992) with photometric detection. Both methods are simple and fast, with sample throughput ranging between $30-90 \mathrm{~h}^{-1}$.

Other recently proposed methods are based on liquid chromatography (RodríguezDelgado et al., 2001; Carrero-Gálvez et al., 1994) and capillary electrophoresis (Pazourek et al., 2000), which have been shown to be faster and more sensitive than the official or usual methods, but they do not provide an overall index of the total polyphenols content in wine. They give only the individual content of the most relevant phenolic compounds.

\section{Continuous vs. Discontinuous Methods}


In general, the most usual methods for monitoring polyphenols present in wines are based on an overall index. Continuous methods yield better results than do discontinuous methods with higher sample throughput and similar precision and accuracy. Continuous methods for individual multidetermination of phenolic compounds are useful in order to obtain phenol profiles but they are not useful for industrial process monitoring.

\section{Other Determinations: Soluble Solids, pH, and Color}

\section{Soluble Solids}

Soluble solids refer to all substances, other than water, that are in the liquid phase of wine or must. They also receive other names such as volumic mass $\left(\mathrm{g} \mathrm{mL}^{-1}\right)$, relative density, Oechsle $\left({ }^{\circ} \mathrm{Oe}\right)$, Brix degree $(\% \mathrm{~m} / \mathrm{m}$ sacarose $)$, and refractive index, depending on both the units and determination procedure. The official method for the analysis of soluble solids in wine is picnometry (OIV, 1990, p. 41).

There are, in the literature, only two continuous methods for the determination of soluble solids in wines, both based on flow injection with piezoelectric (Magna et al., 1996) or photometric detection (Mataix and Lugue de Castro, 2001). The first one presents a linear response between $0.5-20$ Brix degree, with a detection limit of $0.3 \%$ and precision lower than $1.45 \%$, in terms of RSD. The second method is based on the displacement of a light beam when the refractive index of the medium changes, with precision less than $2.3 \%$ in terms of RSD and sample throughput of $90 \mathrm{~h}^{-1}$.

\section{pH}

Measurement \& $\mathrm{pH}$ has traditionally been year based on the use of the well-known calomel-glass electrode. Presently, a new generation of FT-IR instruments enables the determination of $\mathrm{pH}$ together with others; namely, ethanol, titratable acidity, volatile acidity, reducing sugars, etc. with good correlation with the reference laboratory methods (Kupina and Shrikhande, 2003).

\section{Color}

The reference method to determine color in wines is the tri-stimulus method (OIV, 1990), based on the use of three special filters combined with a light source and a photocell. The most usual method to determine color in wine is based on photometric measurements at 420, 520, and $620 \mathrm{~nm}(\mathrm{OIV}, 1990$, p. 29). Another method, known as the Cielab system (Cruz-Ortiz et al., 1995), is based on the use of chromatic diagrams.

No new methods for color have been proposed, probably due to the simplicity and nature of this determination.

\section{Conclusions}

One of the conclusions from this study is that some of the traditional methods, namely, soluble solids, $\mathrm{pH}$, or color have not been modified in recent years, whereas others, such as those for organic acids, ethanol, volatile acidity, iron, or polyphenols, have experienced noticeable improvements in addition to the appearance of new methods as deduced from the literature.

Methods in the literature do not usually fulfill the requirements of the OIV to validate an usual method of analysis vs. a reference one. Most proposed methods do not accomplish 
the minimum period of continuous application (a month) in order to establish both a reproducibility value according to this protocol, and the number of samples used for repeatability (30 pairs of samples) and reliability studies (50 samples). Traceability is broken by using unofficial reference methods that do not guarantee the accuracy of the results obtained. The fact that most methods described in the literature do not accomplish the OIV validation protocol does not mean that they are useless for the analysis of wines. The conclusion is that the results obtained with these new methods cannot be compared with the reference or official ones and, therefore, they lack traceability (a mandatory requirement to obtain quality data). An in-depth validation of the most promising methods would open new perspectives on potential change of both official and usual methods in Enology.

Continuous methods, when used for routine analyses, are useful tools to minimize the analysis time, to reduce reagent consumption, and to increase the number of analyses in wineries. In general, the new methods are faster than are traditional methods, with equal or lower sensitivity, but with sufficient precision for winery requirements. This last aspect makes them suitable for monitoring fermentation and post-fermentation processes and, sometimes, for quality control of the final product. The rapidity of continuous methods could be the starting point for more frequent analyses, which would result in better knowledge of wine processing and aging, and better quality of the final product as a result.

It is important to emphasize the growing use of multidetermination methods based on FTIR, which provide wide information about the target sample. The main drawback of these methods is the need for proper assessment studies in order to validate the results. Continuous updating of these methods, as a consequence of changes in the wine produced according to the annual characteristics of the raw material, is mandatory. The updating process could be the seed for incipient research in wineries, which would become the first step to start research and development, which are absent in most wineries at present.

\section{Acknowledgment}

Spain's Comisión Interministerial de Ciencia y Tecnología (CICyT) is thanked for financial support (Project BQU-2003-01333).

\section{References}

Amerine, M. A., Ough, C. S. (1976). Análisis de Vinos y Mostos, Acribia, ed.: Zaragoza.

Amerine, M. A., Ough, C. S. (1976a). Análisis de Vinos y Mostos; Acribia, ed.: Zaragoza, p. 58 .

Amerine, M. A., Ough, C. S. (1976b). Análisis de Vinos y Mostos. Acribia, ed.: Zaragoza, p. 57.

Amerine, M. A., Ough, C. S. (1976c). Análisis de Vinos y Mostos. Acribia, ed.: Zaragoza, p. 58.

Amerine, M. A., Ough, C. S. Análisis de Vinos y Mostos. Acribia, ed.: Zaragoza, p. 59. 
Amerine, M. A., Ough, C. S. Análisis de Vinos y Mostos Acribia, ed.: Zaragoza, 1976, p. 112.

Amerine, M. A., Ough, C. S. Análisis de Vinos y Mostos. Acribia, ed.: Zaragoza, 1976; 129.

Andersen, S. K., Hansen, P. W., Andersen, H. V. (2000). Vibrational Spectroscopy in the Analysis of dairy products and wine. Handbook of Vibrational Spectroscopy, Chalmers, J. M., Griffiths P. R., (eds), John Wiley \& Sons Ltd.: Chichester.

Anon. (1998) Hewlett-Packard-Peack. 1:14-15.

Appelqvist, R., Hansen, E. H. (1990) Determination of glucose in fermentation processes by means of an online coupled flow-injection system using enzyme sensors based on chemically modified electrodes. Anal. Chim. Acta 235(2):265-271.

Araujo, A. N., Couto, C. M. C. M., Lima, J. L. F. C., Montenegro, M. C. B. S. M. (1998). Determination of sulphur dioxide in wines using a flow-injection analysis system with potentiometric detection. J. Agric. Food Chem. 46(1):168-172.

Araujo, A. N., Lima, J. L. F. C., Rangel, A. O. S. S., Segundo, M. A. (2002). Sequentialinjection system for the spectrophotometric determination of reducing sugars in wines. Talanta 52(1):59-66.

Arnes, S., Miles, W. S, Mruzinsky, P. (1997). Automated analysis of alcohol in wine. Lab-2000 11(7):102-104.

Atanassov, G. T., Lima, R. C., Mesquita, R. B. R., Rangel, A. O. S. S., Toth, I. V. (2000). Spectrophotometric determination of carbon dioxide and sulphur dioxide in wines by flow injection. Analusis 28(1):77-82.

Azevedo, C. M. N., Araki, K., Toma, H. E. (1999). Determination of sulphur dioxide in wines by gas-diffusion flow-injection analysis utilizing modified electrodes with electrostatically assembled films of tetraruthenated porphyrin. Anal. Chim. Acta 387(2):175-180.

Baldo, M.A., Daniele, S., Mazzocchin, G. A. (1993). Voltammetry with micro-electrodes in wine: determination of total acidity. Anal. Chim. Acta 272(1):151-159.

Baldo, M. A., Salvatore, D., Mazzocchin, G. A. (1994). Voltammetric determination of free sulphur dioxide in wines using platinum and gold disc micro-electrodes. Analyst 119(6):1239-1245. 
Baluja-Santos, C., González-Portal, A. (1992). Application of hydride generation to atomicabsorption-spectrometric analysis of wines and beverages: a review. Talanta 39(4):329-339.

Barjat, H., Belton, P. S., Goodfellow, B. J. (1993). Rapid-scan correlation NMR spectroscopy for food analysis. Food Chem. 48(3):307-312.

Barjat, H., Belton, P. S., Goodfellow, B. J. (1993). Use of rapid-scan correlation nuclear magnetic resonance spectroscopy as a quantitative analytical method. Analyst 118(1):7377.

Barros, F. G., Tubino, M. (1992). Conductimetric and spectrophotometric determination of the volatile acidity of wines by flow injection. Analyst 117:917-919.

Bartroli, J., Escalada, M., Jiménez-Jorquera, C., Alonso, J. (1991). Determination of total and free sulphur dioxide in wine by flow-injection analysis and gas-diffusion using paminoazobenzene as the colorimetric reagent. Anal. Chem. 63(21):2532-2535.

Belton, P. S., Gadsby, P. (1992). Rapid-scan [correlation] NMR spectroscopy delivers structural analysis for food quality control. Lab Equip Dig. 30(3):11-13.

Bi, L. J., Gu, Z. Y. (2000) Reversed-phase HPLC determination of organic acids in wine after solidphase extraction. Lihua Jianyan Huaxue Fence 36(4):163-165.

Bilitewski, U., Chemnitius, G. C., Rueger, P., Schmid, R. D. (1992). Miniaturized disposable biosensors. Sens. Actuators B7(1-3):351-355.

Billingsley, A., Parker, M., Bowden, P., Burglass, A. J. (1996). Radial-compression reversed-phase HPLC analysis of aliphatic acids in grape juice and wine. Analusis 24(2):29-30.

Boujtita, M., Chapleau, M., El-Murr, N. (1996). Biosensors for analysis of ethanol in food: effect of the pasting liquid. Anal. Chim. Acta 319(1-2):91-96.

Buglass, A. J., Lee, S. H. (2000) Elimination of amino-acid interferences in the chiral ligandexchange chromatographic analysis of lactic acid enantiomers in wine. J. Chrom. Sci. 38(5): 207-210.

Calull, M., Marce, R.M., Borrull, F. (1992). Determination of carboxylic acids, sugars, glycerol and ethanol in wine and grape must by ion-exchange high-performance liquid chromatography with refractive index detection. J. Chromatogr. 590(2):215-222.

Calull, M., Marce, R. M., Borrull, F. (1992) Determination of carboxylic acids, sugars, glycerol and ethanol in wine and grape must by ion-exchange high-performance liquid chromatography with refractive index detection. J. Chromatogr. A 590(2):215-222. 
Capitán-García, F., Checa, R., Avidad, Capitán-Vallvey, L.F. (1995). Determination of iron at $\mathrm{ng} / \mathrm{ml}$ level by solid phase spectrophotometry after preconcentration on cation exchange filters. Talanta 42(5):711-715.

Capitán-Vallvey, L. F., Arroyo, E., Berenguer, C., Fernández-Ramos, M. D., Avidad, R. (2001). Single-use optical sensor for the determination of iron in water and white wines. Fresenius J. Anal. Chem. 369(2):139-144.

Cardwell, T. J., Cattrall, R. W., Chen, G. N., Iles, P. J., Hamilton, I. C., Scollary, G. R. (1991b) Determination of sulphur dioxide in white wines by flow injection with electrochemical detection. Electroanalysis 3(8):859-863.

Cardwell, T. J., Cattrall, R. W., Chen, G. N., Scollary, G. R., Hamilton, I. C. (1991a). Determination of free sulphur dioxide in red wine by alternating current voltammetry. Analyst 116(3):253-256.

Cardwell, T. J., Cattrall, R. W., Chen, G. N., Scollary, G. R., Hamilton, I. C. (1993). Determination of sulphur dioxide in wines and beverages by flow-injection analysis with reductive amperometric detection and electrolytic clean-up. J. AOAC 76(6):1389-1393.

Cardwell, T. J., Cattrall, R. W., O'Connell, G. R., Petty, J. D., Scollary, G.R. (1992). Potentiometric detectors for the determination of acidity by discontinuous flow analysis. Electroanalysis 4(8):805-810.

Cardwell, T. J., Christophersen, M. J. (2000). Determination of sulphur dioxide and ascorbic acid in beverages using a dual channel flow injection electrochemical detection system. Anal. Chim. Acta 416(1):105-110.

Carrero-Gálvez, M., García-Barroso, C., Pérez-Bustamente, J. A. (1994) Analysis of polyphenolic compounds of different vinegar samples. Z. Lebensm Unters Forsch 199(1):29-31.

Casella, I. G., Gatta, M., Desimoni, E. (1998). Applications of a copper-modified gold electrode for amperometric detection of polar aliphatic compounds by anion-exchange chromatography. J. Chromatogr., A. 814(1-2):63-70.

Castineira, A., Peña, R. M., Herrero, C., García-Martín, S. (2000). Simultaneous determination of organic acids in wine samples by capillary electrophoresis and UV detection: optimization with five different background electrolytes. J. High Resolut. Chromatogr. 23(11):647-652.

Celeste, M., Tomás, C., Cladera, A., Estela, J. M., Cerda, V. (1992). Enhanced automatic flowinjection determination of the total polyphenol index of wines using Folin-Ciocalteu reagent.Anal. Chim. Acta 269(1):21-28. 
Chen, S. G., Hu, Q. A. (1993). Determination of organic acids in foods by highperformance liquid chromatography. Sepu 11(3):175-177.

Chen, Z., Yu, J. J., Hibbert, D. B. (1997). Flow-injection, amperometric determination of ethanol in wines after solid-phase extraction. Electroanalysis 9(7):541-543.

Chmilenko, F. A., Baklanova, L. V. J. (1997). Atomic absorption determination of standardized metal impurities in wines using ultrasound. Anal. Chem. 52(11):1093-1098.

Cladera, A., Gómez, E., Estela, J. M., Cerdá, V. (1991) Determination of iron by flowinjection based on the catalytic effect of the iron(III)-ethylenediaminetetra-acetic acid complex on the oxidation of hydroxylamine by dissolved oxygen. Analyst 116(9):913917.

Coquet, A., Haerdi, W., Degli-Agosti, R., Veuthey, J. L. (1994). Determination of sugars by liquid chromatography with post-column catalytic derivatization and fluorescence detection. Chromatographia 38(1-2):12-16.

Cruz-Ortiz, M., Herrero, A., Sagrario-Sanchez, M., Sarabia, L. A., Iñiguez, M. (1995). Modelling the relation between CieLab parameters and sensory scores for quality control of red wine colour. Analyst 120(12):2793-2798.

Cserhati, T., Forgacs, E., Morais, M. H., Mota, T. (2000). Chromatography in wine analysis. LC-GCEurope 13(4):254-664.

Dai, G. S., Peng, R. M., Deng, X. W., Yuan, B. C., Song, J. Y. (1996). Absorptiophotometric determination of ethanol in wine with eosin inner ester. Lihua. Jianyan, Huaxue Fence 32(1):26-27.de Campos-Costa, R. C., Araujo, A. N. (2001) Determination of $\mathrm{Fe}(\mathrm{III})$ and total $\mathrm{Fe}$ in wines by sequential injection analysis and flame atomic absorption spectrometry. Anal. Chim. Acta 438 (1-2):227-233.

Decnop-Weever, L. G., Kraak, J. C. (1997). Determination of sulphite in wines by gasdiffusion flowinjection analysis utilizing spectrophotometric $\mathrm{pH}$-detection. Anal. Chim. Acta 337(2): 125-131.

Delgado-Reyes, F., Papaefstathiou, I., Fernández-Romero, J. M.; Luque de Castro, M. D. (1998). Monitoring ethanol production during wine fermentation processes by a pervaporation-enzymic derivatisation approach. Analyst 123:2367-2372.

Dell'Oro, V. (1991). Applications of nuclear magnetic resonance spectrometry in [o]enology. Vini.Ital. 33(2):27-32.

Edberg, U. (1993). Enzymic determination of sulphite in foods. NMKL interlaboratory study. J. AOAC 76(1):53-58. 
Escobal, A., González, J., Iriondo, C., Laborra, C. (1997). Liquid chromatographic determination of organic acids in txakoli from Bizkaia. Food Chem. 58(4):381-384.

Escobal, A., Iriondo, C., Laborra, C., Elejalde, E., González, I. (1998). Determination of acids and volatile compounds in red Txakoli wine by high-performance liquid chromatography and gas chromatography. J. Chromatogr. A 823(1-2):349-354.

Escobal, A., Iriondo, C., Laborra, C., Ulibarrena, E. (1995). Application of FAAS and GFAAS to the control of cloudiness in txakoli wine. At. Spectrosc. 16(4):162-164.

Falque-López, E., Fernández-Gómez, E. (1996). Simultaneous determination of the major organic acids, sugars, glycerol, and ethanol by HPLC in grape musts and white wines. $J$. Chromatogr. Sci. 34(5):254-257.

Fang, G. Z., Zhang, L. (1993) Sequential fluorescent determination of iron and cobalt in wine with 2,6,7-trihydroxy-9-styryl-fluorone-3 and surfactant by microwave digestion without separation. Fenxi Ниахие 21(2):170-173.

Fatibello-Filho, O., da Cruz Vieira, I. (1997). Flow injection spectrophotometric determination of sulphite using a crude extract of sweet potato root [Ipomoea batatas (L.) Lam.] as a source of polyphenol oxidase. Anal. Chim. Acta 354(1-3):51-57.

Fauhl, C., Wittkowski, R. Z. (1996) Online proton NMR to facilitate tube preparation in SNIF-NMR analysis. Lebensm. Unters. Forsch. 203(6):541-545.

Feng, Z., Zhou, B. (1992). Rapid determination of lactic acid in food by gas chromatography. Sepu 10(1):44-46.

Flanzy, C. (2000). Enología: Fundamentos Científicos y Tecnológicos. AMV ed., Mundi Prensa Ed.:Madrid. pp. 43-44.

Ga, R. D., Liu, Y. (1996). Determination of trace iron(III) with thiocyanate/resin phase spectrophotometry. Fenxi Ниахие 24(11):1309-1311.

Gaiao, E. N., Honorato, R. S. M, Santos, S. R. B., Araujo, M. C. U. (1999). An automated flowinjection titrator for spectrophotometric determinations of total acidity in wines, using a single standard solution and gradient calibration. Analyst 124(11):17271730 .

Gao, Z. F., Fu, C. G. (1994). Determination of organic acids by nonsuppressed ionexclusion chromatography with conductometric detection. Fenxi Huaxue. 22(12):12341237. García-de-María, C., Manzano-Muñoz, T., Alonso-Mateos, A., García-de-Maria, L. (1991). Enzymic determination of free L-(-)-malic acid in must and wine by stopped-flow flow-injection analysis. Anal. Chim. Acta 247(1):61-65. 
García-Jares, C., Medina, B. (1995). Prediction of some physico-chemical parameters in red wines from ultraviolet-visible spectra using a partial least-squares model in latent variables. Analyst 120(7):1891-1896.

García-Jares, C. M., Medina, B. (1997). Application of multivariate calibration to the simultaneous routine determination of ethanol, glycerol, fructose, glucose and total residual sugars in botrytizedgrape sweet wines by means of near-infra-red reflectance spectroscopy. Fresenius J. Anal. Chem. 357(1):86-91.

García-Mullor, S., Sánchez-Cabezudo, M., Miranda-Ordieres, A.J., López-Ruiz, B. (1996). Alcohol biosensor based on alcohol dehydrogenase and Meldola Blue immobilized into a carbon paste electrode. Talanta 43(5):779-784.

García-Prieto, A. M., Pérez-Pavón, J. L., Moreno-Cordero, B. (1994). Gas diffusion and micellar catalysis in the flow-injection determination of sulphite. Analyst 119(11):24472452.

Gillis, M., Comtat, M. (1995) Contribution of biosensors to oenology and constraints associated with their use. Sens. Actuators, B B27(1-3):417-420.

Gomes, M. T., Rocha, T. A., Duarte, A. C., Oliveira, J. P. (1996). Determination of sulphur dioxide in wine using a quartz crystal microbalance. Anal. Chem. 68(9):15611564 .

González-Rodríguez, J., Pérez-Juan, P., Luque de Castro, M. D. (2001). Semiautomatic flow-injection method for determination of volatile acidity in wines. J. AOAC Int. 84(6):1846-1850.

González-Rodríguez, J., Pérez-Juan, P.M., Luque de Castro, M.D. (2002). Method for the simultaneous determination of total polyphenol and anthocyan indexes in red wines using a flow injection approach. Talanta 56:53-59.

González-Rodríguez, J., Pérez-Juan, P. M., Luque de Castro, M. D. (2002). Sequential spectrophotometric determination of methanol and iron in vinegar by a flow injectionpervaporation method. Anal. Bioanal. Chem. 374:120-125.

González-Rodríguez, J., Pérez-Juan, P. M., Luque de Castro, M. D. (2003) Determination of etanol in beverages by flow injection, pervaporation and density measurements. Talanta 59: 691-696.

Guan, J. R., Deng, C. R., Wang, J. S., Wang, S. R. (1993). High-performance liquidchromatographic analysis of phenacyl esters of carboxylic acids directly esterified in wines. Sepu11(5):282-285. 
Hartmann, P., Haswell, S. J., Grasserbauer, M. (1994). Monitoring of reducing sugars by flowinjection analysis using p-hydroxybenzoic acid hydrazide. Anal. Chim. Acta 285(1):1-8.

Hemmi, A., Yagiuda, K., Funazaki, K., Ito, S., Asano, Y., Imato, T., Hayashi, K., Karube, I. (1995). Development of a chemiluminescence detector with photodiode detection for flow-injection analysis and its application to L-lactate analysis. Anal. Chim. Acta 316(3):323-327.

Hsieh, Y., Crouch, S. R. (1993). Stopped-flow, air-segmented continuous flow: kinetic determinations of glucose and phosphate in wine and serum samples. Anal. Chim. Acta 284(1):159-166

Hu, J. Y., Li, J. M. (1993). Gas-chromatographic analysis of low-boiling organic acids in wine and fermented liquid. Sepu 11(2):87-89.

Huang, Y. L., Kim, J. M., Schmid, R. D. (1992). Determination of sulphite in wine through flow injection analysis based on the suppression of luminol chemiluminescence. Anal. Chim. Acta 266(2):317-323.

Igler, A., Rauter, W. (1996) Capillary gas chromatographic determination of synthetic DL-malic acid in fruit. Z. Lebensm Unters Forsch. 203(3):283-286.

Imabayashi, S. I., Kong, Y. T., Watanabe, M. (2001). Amperometric biosensor for polyphenol based on horseradish peroxidase immobilized on gold electrodes. Electroanalysis 13(5):408-412.

Jun, X., Lima, J. L. F. C., Montenegro, M. C. B. S. M. (1996) Simultaneous determination of inorganic anions and carboxylic acids in wine using isocratic separation on a permanently coated reversed-phase column and UV indirect detection. Anal. Chim. Acta 321(2-3):263-271.

Katrlik, J., Svorc, J., Stredannsky, M., Miertus, S. (1998). Composite alcohol biosensors based on solid binding matrix. Biosen-Bioelectron 13(2):181-191.

Kaufmann, A. (1993) Survey and application of HPLC analysis of acids and sugars in wine. Mitt-Geb-Lebensmittelunters 84(3):311-333.

Kawamura, Y., Kubo, N., Arata, H., Ito, Y., Tamura, M.; Yamamoto, K. (1994) A microbial sensor for determination of sulphite in wines. J. AOAC 77(4):1052-1056.

Kiba, N., Inagaki, J., Furusawa, M. (1995). Chemiluminometric flow-injection method for determination of free L-malate in wine with co-immobilized malate dehydrogenase/NADH oxidase. Talanta 42(11):1751-1755. 
Kiba, N., Inoue, T., Furusawa, M. (1991). Flow-injection system for the fluorimetric determination of fructose with an immobilized mannitol dehydrogenase reactor. Anal. Chim. Acta 243(2):183-186.

Kiba, N., Oguchi, M., Furusawa, M. (1993). Determination of L-malate in wine by flow injection with co-immobilized malate dehydrogenase-oxaloacetate decarboxylase. Talanta 40(8):1163-1165.

Kilmartin, P. A., Zou, H. L., Waterhouse, A.L. (2001) A cyclic voltammetry method suitable for characterizing antioxidant properties of wine and wine phenolics. J. Agric. Food Chem. 49(4): 1957-1965.

Kosir, I. J., Kocjancic, M., Ogrinc, N., Kidric. (2001). Use of SNIF-NMR (site-specific natural isotopic fractionation by hydrogen-2 nuclear magnetic resonance) and IRMS (isotope ratio mass spectrometry) in combination with chemometric methods for the determination of chaptalisation (adulteration) and geographical origin of wines (the example of Slovenian wines). Anal. Chim. Acta 2001, 429(2), 195-206.

Kuban, P., Janos, P., Kuban, V. (1998). Gas diffusion-flow injection determination of free and total sulphur dioxide in wines by conductometry. Collect Czech Chem. Commun. 63(6):770-782.

Kuennecke, W., Schmid, R. D. (1990). Gas-diffusion dilution flow-injection method for the determination of ethanol in beverages without sample pre-treatment. Anal. Chim. Acta 234(1):213-220.

Kupina, S. A., Shrikhande, A. J. (2003). Evaluation of a Fourier Transform Infrared instrument for rapid quality-control wine analyses. Am. J. Enol. Vitic. 642:131-135.

Lima, J. L. F. C., Lopes, T. I. M. S., Rangel, A. O. S. S. (1998) Enzymatic determination of L-(+)-lactic and L-(-)malic acid in wines by flow-injection spectrophotometry. Anal. Chim. Acta 366(1-3): 187-191.

Lin, J. M., Hobo, T. (1996). Flow-injection analysis with chemiluminescent detection of sulphite using sodium carbonate-sodium bicarbonate-copper ion system. Anal. Chim. Acta 323(1-3):69-74.

Linget, C., Netter, C., Heems, D., Verette, E. (1998). Online dialysis with HPLC for the automated preparation and analysis of amino-acids, sugars and organic acids in grape juice and wines. Analusis 26(1):35-39.

Lobo, M. J., Miranda, A. J., Tunon, P. (1996). Comparative study of some phenoxazineand phenothiazine-modified carbon-paste electrodes for ethanol determination. Electroanalysis 8(6):591-596. 
Lodi, G., Betti, A., Brandolini, V., Menziani, E., Tosi, B. (1994) Automated multiple development HPLC analysis of sugars on hydrophilic layers. I. Amino layers. J. Planar Chromatogr. Mod. 7(1):29-33.

Lopes, T. I. M. S., Rangel, A. O. S. S., Lima, J. L. F. C., Montenegro, M. C. B. S. M. (1995). Construction and use of a tubular picrate ion-selective electrode for reducing sugar determination in port wine by flow-injection analysis. Anal. Chim. Acta 308(13):122-128.

Luo, H. Q., Liu, S. P. (1998). Direct determination of ethanol in alcoholic beverages by multiwavelength overlapping near-infra-red absorption spectrometry. Fenxi Ниахие 26(1):97-99.

Luque de Castro, M. D., Luque-García, J. L. (2000). Biosensors in wine production monitoring. Anal. Lett. 33(6):963-996.

Magna, A., Fernando-de-Oliveira, A., Fatibello-Filho, O. (1996). Flow-injection piezoelectric determination of brix in sugar cane juice and in the alcoholic fermentation process. Anal. Lett. 29(13):2411-2419.

Magri, A. D., Magri, A. L., Balestrieri, F., Sacchini, A., Marini, D. (1997). Spectrophotometric micro-method for the determination of ethanol in commercial beverages. Fresenius J. Anal. Chem. 357(7):985-988.

Mallet, S., Arellano, M., Boulet, J. C., Couderc, F. (1999) Determination of tartaric acid in solid wine residues by capillary electrophoresis and indirect UV detection. $J$. Chromatogr. A 853(1-2): 181-184.

Mana, H., Spohn, U. (2001). Sensitive and selective flow-injection analysis of hydrogen sulphite/sulphur dioxide by fluorescence detection with and without membrane separation by gas diffusion. Anal. Chem. 73(13):3187-3192.

Mannino, S., Brambilla, M. (1992). Determination of iron(III) and total iron in wines by constant current potentiometric stripping analysis. Ital. J. Food Sci. 4(1):47-51.

Mataix, E., Luque de Castro, M. D. (1998) Determination of total and free sulphur dioxide in wine by pervaporation-flow injection. Analyst 123(7):1547.

Mataix, E., Luque de Castro, M. D. (1999) Sequential determination of carbon dioxide and free sulphur dioxide in wine by flow-injection pervaporation with in series potentiometric-photometric detection. Fresenius J. Anal. Chem. 365(4):377-380.

Mataix, E., Luque de Castro, M. D. (1999) Sequential determination of total and volatile acidity in wines based on a flow injection-pervaporation approach. Anal. Chim. Acta 381(1):23-28. 
Mataix, E., Luque de Castro, M. D. (2000a). Simultaneous determination of ethanol and glycerol in wines by a flow injection-pervaporation approach with in parallel photometric and fluorimetric detection. Talanta 51:489-496.

Mataix, E., Luque de Castro, M. D. (2000b) Pervaporation prior to gas chromatography for the determination of enological parameters. Chromatographia 52(3-4):205-210.

Winery Analytical Methods 261

Mataix, E., Luque de Castro, M.D. (2001). Determination of L-(-)-malic acid and L-(+)lactic acid in wine by a flow injection-dialysis-enzymic derivatisation approach. Anal. Chim. Acta 428(1):7-14.

Mataix, E., Luque de Castro, M. D. (2001). Simultaneous (or sequential) determination of the total polyphenol index (or I280) and density in wines by flow injection. Analyst, 126(2):251-255.

Mateo, J. J., Jiménez, M. (2000). Monoterpenes in grape juice and wines. $J$. Chromatogr-A. 881(1-2):557-567.

Matissek, R. Schnepel, F. M. Steiner, G. (1992). Análisis de los alimentos. Fundamento, métodos, aplicaciones. Ed. Acribia, S.A., Zaragoza p.124.

Matsumoto, K., Matsubara, H., Hamada, M., Osajima, Y. (1991). Simultaneous determination of glucose, ethanol, glycerol and sulphite in white wine by flow-injection analysis including parallel configuration of immobilized enzyme columns. Nipon Shokuhin Kogyo Gakkaishi 38(8):699-703.

Mattos, I. L., Fernández-Romero, J. M., Luque de Castro, M. D.; Valcárcel, M. (1995). Simultaneous spectrofluorimetric determination of glycerol and ethanol in wine by flow injection using immobilized enzymes. Analyst 120(1):179-182.

Mattos, I. L., Sartini, R. P., Zagatto, E. A. G., Reis, B. F., Giné, M. F. (1998). Spectrophotometric flow-injection determination of ethanol in distilled spirits and wines involving permeation through a silicon tubular membrane Anal. Sci. 14(5):1005-1008.

Miao, J. G., Li, J. Y., Chen, Y. P., Cai, R. X., Zeng, Y. N. (1993). Colour reaction of iron(III) with 2,6,7-trihydroxy-9-(5-bromosalicyl)fluorone. Fenxi Нuaxue 21(12):14141416.

Miertus, S., Katrlik, J., Pizzariello, A., Stredansky, M., Svitel, J., Svorc, J. (1998). Amperometric biosensors based on solid binding matrices applied in food quality monitoring. Biosens. Bioelectron. 13:911-923.

Mohns, J., Kuennecke, W. (1995). Flow analysis with membrane separation and time based sampling for ethanol determination in beer and wine. Anal. Chim. Acta 305(13):241-247. 
Mou, S., Jiang, J., Hou, X. (1992). Separation and detection of organic acids by ionexclusion chromatography. Sepu 10(3):133-136.

Murakami, K., Kakemoto, M., Harada, T. (1991). High-performance liquidchromatographic determination of glucose using an immobilized-enzyme reactor. Bunseki Kagaku 40(3):125-129.

Murakami, K., Kakemoto, M., Ogawa, H. (1996). Simultaneous determination of lactic acid, glutamic acid and glucose by HPLC using an enzyme sensor using photocrosslinkable poly(vinyl alcohol) support as the detector. Nippon Kagaku Kaishi $5: 457-461$.

Nakamura, K., Saegusa, K., Kurosawa, H., Amano, Y. (1993). Determination of free sulphur dioxide in wine by using a biosensor based on a glass electrode. Biosci. Biotechnol. Biochem. 57(3):379-382.

Nanos, C. G., Karayannis, M. I. (1991). Assay of reducing sugars in beverages, wines, honey and marmalades using potentiometric stripping analysis (PSA). Fresenius J. Anal. Chem. 340(4), 253-257.

Navas, M. J., Jiménez, A. M. (1999). Chemiluminescent methods in alcoholic beverage analysis. J. Agric. Food Chem. 47(1):183-189.

Neira, J. Y., Reyes, N., Nóbrega, J. A. (2002). Development of hardware and software for online sample preparation using sequential-injection analysis. Lab. Rob. Autom. 12(5):246-252. Official Methods of Analysis, 11th ed. (1990). Association of Official Analytical Chemists: Washington D.C. p. 144.

Ohtsuki, S., Kunimatsu, N., Takamura, K., Kusu, F. (2001). Determination of the total acid content in wine based on the voltammetric reduction of quinone. Electroanalysis 13(5):404-407. OIV. Office International de la Vigne et du Vin (OIV): Paris, 1990; p. 91. OIV. Recueil des méthodes internationales d'analyse des vins et des mouts; Office International de la Vigne et du Vin (OIV): Paris, 1990; 271.

Olalla, M., González, M. C.; Cabrera, C., López, M. C. (2000) Optimized determination of iron in grape juice, wines, and other alcoholic beverages by atomic absorption spectrometry. J. AOAC Int. 83(1):189-195.

Oliveira, A. F., Fatibello-Filho, O. (1999) Flow-injection-spectrophotometric determination of reducing sugars using a focalized coiled reactor in a domestic microwave oven. Talanta 50(4): 899-904.

Palleschi, G., Volpe, G., Compagnone, D., La-Notte, E., Esti, M. (1994). Bioelectrochemical determination of lactic and malic acids in wine. Talanta 41(6):917923. 
Patz, C. D., David, A., Thente, K., Kuerbel, P., Dietrich, H. (1990). Wine analysis with FTIR spectrometry. Vitic. Enol. Sci. 54(2-3):80-87.

Pazourek, J., González, G., Revilla, A.L., Havel, J. (2000). Separation of polyphenols in Canary Islands wine by capillary zone electrophoresis without preconcentration. $J$. Chromatogr., A 874(1): 111-119.

Pérez-Ponce, A., Garrigues, S., de la Guardia, M. (1996). Vapour generation-Fouriertransform infra-red direct determination of ethanol in alcoholic beverages. Analyst 121(7):923-928.

Pérez-Ruiz, T., Martínez-Lozano, C., Tomás, V., Carrión, F. J. (1993). Flow-injection analysis of formaldehyde and sulphite using the oxidation of p-phenylenediamine by hydrogen peroxide. Int.J. Environ. Anal. Chem. 53(3):195-203.

Peris-Tortajada, M., Puchades, R., Maquieira, A. (1992) Determination of reducing sugars by the neocuproine method using flow-injection analysis. Food Chem. 43(1):6569.

Polo, M. C., Barahona, F., Cáceres, I. (1986). Determination by high-performance liquid chromatography of the principal organic acids in wine. Connaiss Vigne Vin 20(3):175187.

Promsong, L., Sriyudthsak, M. (1995). Thin tin oxide film alcohol-gas sensor. Sens. Actuators B25(1-3):504-506.

Puchades, R., Herrero, M. A., Maquieira, A., Atienza, (1991). Simultaneous enzymic determination of L-(-)-malic acid and L-(+)-lactic acid in wine by flow-injection analysis. J. Food Chem.

42(2):167-182.

Pulido-Tofino, P., Barrero-Moreno, J. M., Pérez-Conde, M. C. (2000). A flow-through fluorescent sensor to determine iron(III) and total inorganic iron. Talanta 51(3):537-545.

Radin, L., Pronzato, C., Casareto, L., Calegari, L. (1994). Tartaric acid in wines may be useful for preventing renal calculi: rapid determination by HPLC. J. Liq. Chromatogr. 17(10):2231-2246.

Rangel, A. O. S. S., Toth, I.V. (1998). Sequential determination of titratable acidity and tartaric acid in wines by flow-injection spectrophotometry. Analyst 123(4):661-664.

Rangel, A. O. S. S., Toth, I. V. (2000). Enzymic determination of ethanol and glycerol by flowinjection parallel multisite detection. Anal. Chim. Acta 416(2):205-210. 
Rapp, A., Versini, G. (1996). Volatile phenolic compounds of wine. Dtsch. Lebensm. Rundsch 92(2):42-48.

Recueil des méthodes internationales d'analyse des vins et des mouts. (1990). Office International de la Vigne et du Vin (OIV): Paris.

Recueil des méthodes internationales d'analyse des vins et des mouts. (1990). Office International de la Vigne et du Vin (OIV): Paris. p. 29.

Recueil des méthodes internationales d'analyse des vins et des mouts. (1990). Office International de la Vigne et du Vin (OIV): Paris. p. 41.

Recueil des méthodes internationales d'analyse des vins et des mouts (1990). Office International de la Vigne et du Vin (OIV) : Paris, p. 61.

Recueil des méthodes internationales d'analyse des vins et des mouts. (1990) Office International de la Vigne et du Vin (OIV): Paris, p. 155.

Recueil des méthodes internationales d'analyse des vins et des mouts. (1990). Office International de la Vigne et du Vin (OIV): Paris, p. 159.

Recueil des méthodes internationales d'analyse des vins et des mouts. (1990). Office International de la Vigne et du Vin (OIV): Paris. p. 169.

Recueil des méthodes internationales d'analyse des vins et des mouts. (1990). Office International de la Vigne et du Vin (OIV): Paris. p. 179.

Recueil des méthodes internationales d'analyse des vins et des mouts. (1990). Office International de la Vigne et du Vin (OIV): Paris, p. 195.

Recueil des méthodes internationales d'analyse des vins et des mouts; (1990). Office International de la Vigne et du Vin (OIV): Paris. p.221.

Recueil des méthodes internationales d'analyse des vins et des mouts; Office International de la Vigne et du Vin (OIV): Paris. p. 222.

Recueil des méthodes internationales d'analyse des vins et des mouts. (1990). Office International de la Vigne et du Vin (OIV): Paris, p. 269.

Regulation (EEC) $\mathrm{N}^{\mathrm{o}} 2676 / 90$ of the Council of May 29th. (1989). European Commission: Brussels.

Resolution OENO 6/2000. http://www.oiv.int/Database/Images/Client/Oeno\%2062000es.pdf (accessed May 2002) 
Rezende, M. O., Mottola, H. A. (1994). Selective continuous flow-stopped flowcontinuous flow determination of sulphite in white wines using immobilized sulphite oxidase on a rotating reactor. Analyst 119(9):2093-2096.

Ribereau-Gayon, J.; Peinaud, E. Analyse et controle des vins. 2nd ed., Casa Libraire Polytechnique Ch. Béranger: Paris, 1958 Spanish version, C. Diez de Betancourt, ed. Aguilar: Madrid, 1962.

Ribereau-Gayon, J.; Peinaud, E. Analyse et controle des vins, 2nd Ed.; Casa Libraire Polytechnique Ch. Béranger, Ed.:Paris, 1958; Spanish version of C. Diez de Betancourt. Aguilar, Ed.: Madrid, 1962; 227.

Ribereau-Gayon, J.; Peinaud, E. (1958). Analyse et controle des vins, 2nd Ed., Ed. Casa Libraire Polytechnique Ch. Béranger: Paris, 1958; Spanish version, C. Diez de Betancourt ed. Aguilar: Madrid, 1962; p. 34.

Ribereau-Gayon, J., Peinaud, E. (1958). Analyse et controle des vins, 2nd ed.; Casa Libraire Polytechnique Ch. Béranger, Ed.: Paris, 1958; Spanish versión of C. Diez de Betancourt. Aguilar, Ed.: Madrid, 1962; 228

Ribereau-Gayon, J., Peinaud, E. (1998). Analyse et controle des vins. 2nd ed., Casa Libraire Polytechnique Ch. Béranger Ed.: Paris, 1958; Spanish version of C. Diez de Betancourt. Aguilar, Ed.: Madrid, 1962; 222.

Ribereau-Gayon, J., Peinaud, E., Sudraud, P. (1976). Traité d'oenologie. Sciencies et techniques duvin. Vol. 1. Dunod.: Paris, p. 254.

Ribereau-Gayon, J., Peinaud, E., Sudraud, P. (1976). Traité d'oenologie. Sciencies et techniques duvin. Vol. 1 Dunod.: Paris, p. 256.

Ribereau-Gayon, J., Peinaud, E., Sudraud, P. (1976). Traité d'oenologie. Sciencies et techniques duvin. Vol. 1 Dunod.: Paris. p. 272.

Ribereau-Gayon, J., Peinaud, E., Sudraud, P. (1976). Traité d'oenologie. Sciencies et techniques du vin. Vol. 1 Dunod.: Paris. p. 274.

Ribereau-Gayon, P., Glories, Y., Maujean, A. Dubordieu, D. (2000). Handbook of Enology, The Chemistry of Wine Stabilization and treatments. Vol 2. John Wiley \& Sons Ltd. Ed.: Chichester, p. 158.

Richter, P., Luque de Castro, M. D., Valcárcel, M. (1993). Spectrophotometric flowthrough sensor for the determination of sulphur dioxide. Anal. Chim. Acta 283(1):408413.

Rodríguez-Delgado, M. A., Malovana, S., Pérez, J. P., Borges, T., García-Montelongo, F. J. (2001). Separation of phenolic compounds by high-performance liquid 
chromatography with absorbance and fluorimetric detection. J. Chromatogr., - A 912(2):249-257.

Rueger, P., Bilitewski, U., Schmid, R. D. (1991). Glucose and ethanol biosensors based on thick film technology. Sens. Actuators B4(3-4):267-271.

Sales, M. G. F., Amaral, C. E. L., Delerue-Matos, C. M. (2001). Determination of tartaric acid in wines by FIA with tubular tartrate-selective electrodes. Fresenius J. Anal. Chem. 369(5):446-450.

Sánchez-Muñoz, G., García-Romero, E., Pérez-Coello, M. S., Martín-Álvarez, P. J. (1992). Determination of glycerol in wines by high-performance liquid chromatography: comparison with enzymic method. J. Chromatogr. 623(1):43-47.

Sarudi, I., Kelemen, J. (1998). Determination of free sulphur and total sulphur dioxide in wines by an ICP AES method. Talanta 45(6):1281-1284.

Sasaki, Y., Tagashira, S., Murakami, Y., Kai, S. (1993). Spectrophotometric determination of the alcohol content of alcoholic drinks with bis(OO'-dipropyl dithiophosphato)nickel(II). Anal. Sci. 9(4):483-486.

Schindler, R., Vonach, R., Lendl, B., Kellner, R. (1998). A rapid automated method for wine analysis based upon sequential-injection (SI)-FTIR spectrometry. Fresenius J. Anal. Chem. 362(1): 130-136.

Schuhmann, W. (1991). Amperometric substrate determination in flow-injection systems with polypyrrole-enzyme electrodes. Sens. Actuators, B 4(1):41-49.

Scollary, G. R. Metals in wine: contamination, spoilage and toxicity. Analusis 1997, 25(3), 26-30. Sebecic, B., Pavisic-Strache, D., Dragojevic, I. Trace elements in wine from Croatia. Dtsch Lebensman Rundsch 1998 94(10):341-344.

Segundo, M. A., Rangel, A. O. S. S. (2001). A gas diffusion sequential-injection system for the determination of sulphur dioxide in wines. Anal. Chim. Acta 427(2):279-286.

Segundo, M. A., Rangel, A. O. S. S., Cladera, A., Cerdá, V. (2000). Multisyringe flow system: determination of sulphur dioxide in wines. Analyst 125(8):1501-1505.

Seiler, K., Wang, K., Kuratli, M., Simon, W. (1991). Development of an ethanolselective optrode membrane based on a reversible chemical recognition process. Anal. Chim. Acta 244(2):151-160.

Serra, B., Reviejo, A. J., Parrado, C., Pingarrón, J. M. Biosens. (1999) Graphite-teflon composite bienzyme electrodes for the determination of L-lactate: application to food samples. Bioelectron.14(5):505-513. 
Silva, R. L. G. N. P., Silva, C. S., Nóbrega, J. A., Neves, E. A. (1998). Anal. Lett. 31(13): 2195-2208.

Stredansky, M., Pizzariello, A., Stredanska, S., Miertus, S. (1999). Determination of Dfructose in foodstuffs by an improved amperometric biosensor based on a solid binding matrix. Anal. Comm. 36(2):57.

Su, X. L., Wei, W. Z., Nie, L. H., Yao, S. Z. (1998). Flow-injection determination of sulphite in wines and fruit juices by using a bulk acoustic wave impedance sensor coupled to a membrane separation technique. Analyst 123(2):221-224.

Suye, S., Yoshihara, N., Inuta, S. (1992). Spectrophotometric determination of L-malic acid with a malic enzyme. Biosci. Biotechnol. Biochem. 56(9):1488-1489.

Svorc, J., Miertus, S., Katrlik, J., Stredansky, M. (1997). Composite transducers for amperometric biosensors. The glucose sensor. Anal. Chem. 69(11):2086-2090.

Tarnowski, D. J., Korzeniewski, C. (1996). Amperometric detection with membranebased sampling for percent-level determinations of ethanol. Anal. Chim. Acta. 332(23):111-121.

Technique Internal Paper, Boehringer Mannheim Cat. № 428191.

Thanh, N. T. K., Decnop-Weever, L. G., Kok, W. T. (1994). Determination of sulphite in wine by flow-injection analysis with indirect electrochemical detection. Fresenius $J$. Anal. Chem. 349(6):469-472.

Toral, M. I., Almendrades, C. (1991). Extraction-spectrophotometric and derivativespectrophotometric determination of trace amounts of iron as the ion-association iron(II)3-(4-phenyl-2-pyridinyl)-5-phenyl-1,2,4-triazine- picrate complex. Anal. Lett. 24(12):2263-2276.

Tsukatani, T., Matsumoto, K. (1999) Enzymatic quantification of L-tartrate in wines and grapes by using the secondary activity of D-malate dehydrogenase. Biosci. Biotechnol. Biochem. 63(10): 1730-1735.

Ukeda, H., Yamamoto, N., Sawamura, M., Kusunose, H. (1995). Microbial sensor for estimating organic acids in wine. Anal. Sci. 11(6):941-945.

Vázquez-Díaz, M. E., Jiménez-Sánchez, J. C., Callejón-Mochón, M., Guiraum-Pérez, A. (1994). Differential-pulse-polarographic determination of iron in acids, waters, fruit juices and wines. Analyst 119(7):1571-1574.

Vereda-Alonso, E., García-de-Torres, A., Rivero-Molina, A., Cano-Pavón, J. M. (1998). Determination of organic acids in wines. A review. Quim. Anal. 17(4):167-175. 
Vonach, R., Lendl, B., Kellner, R. (1998). High-performance liquid chromatography with real-time Fourier-transform infrared detection for the determination of carbohydrates, alcohols and organic acids in wines. J. Chromatogr. 824(2):159-167.

Wagner, K., Bilitewski, U., Schmid, R. D. (1992). Flow-injection analysis of wineaccomplishments and needs. Microchem. J. 45:114-120.

Wagner, K., Bilitewski, U., Schmid, R. D. (1992). Flow-injection analysis of wine accomplishments and needs (II). Microchem. J. 45(2):121-130.

Wang, J., Naser, N. (1995). Amplified biosensing of alcohol based on biocatalytic accumulation of the mediator. Electroanalysis 7(4):362-364.

Wang, J. H., Guan, J. R., Deng, C. G., Guan, X. J., Wang, S. R. (1993). Direct determination of non-volatile acids in wines by reversed-phase high-performance liquid chromatography. Sepu 1993, 11(3):183-185.

Wang, J. S., Guan, J. R., Wang, S. R., Guan, X. J., Ma, P. X., Song, S. Y. (1992). Study of analytical method for sugars in wines by high-performance liquid chromatography (HPLC). Sepu 10(6):369-371.

Wang, X. H., Hu, Z. X., Bai, T. X.; Sun, Y. S. (1997). Preparation and application of a microbial ethanol electrode. Fenxi-Huaxue 25(8):934-936.

Wangsa, J., Danielson, N.D. (1991). Enzymic determination of ethanol by flow-injection analysis using a Kel-F wax-carbon-paste electrode. Electroanalysis 3(7):625-630.

Wu, X. (1992). Use of GDX-103 as stationary phase in the GC analysis of wines. Lihua Jianyan Huaxue Fence 28(4):247-248.

Wu, X. L., Shuo, X. P., Lin, Y. (1999). Decoloration-photometric determination of micro amounts of iron. Lihua Jianyan Huaxue Fence 35(4):158-159.

Xie, X., Suleiman, A. A., Guilbault, G. G., Yang, Z., Sun, Z. (1992). Flow-injection determination of ethanol by fibre-optic chemiluminescence measurement. Anal. Chim. Acta 266(2):325-329.

Yan, J.; Fu, Z.; Nie, X.; Cui, Y.; Ma, L. (1992) Rapid determination of ethanol in Shaoxing wine by headspace chromatography. Lihua Jianyan Huaxue Fence 28(4):214217.

Yao, T., Satomura, M., Nakahara, T. (1994) Simultaneous determination of sulphite and phosphate in wine by means of immobilized enzyme reactions and amperometric detection in a flow-injection system. Talanta 41(12):2113-2119. 
Yebra, M. C., Gallego, M., Valcárcel, M. (1993). Automated determination of reducing sugars [in wine] by atomic-absorption spectrometry. Anal. Chim. Acta 276(2), 385-391.

Yokoi, Y., Matsubara, C., Takamura, K. (1995). Flow-injection determination of sugars in foods by use of a porphinatotitanium(IV) reagent. Bunseki Kagaku 44(5):355-362.

Yoshioka, S., Ukeda, H., Matsumoto, K., Osajima, Y. (1992). Simultaneous flowinjection analysis of L-lactate and L-malate in wine based on the use of enzyme reactors. Electroanalysis 4(5), 545-548.

Yu, H., Liu, Q. L., Guan, L. Z. (1993). Simultaneous analysis of inorganic anions and organic acids by single-column ion chromatography. Sepu 11(2):109-110.

Zeng, H. H., Wang, K. M., Li, D., Yu, R. Q. (1994). Development of an alcohol optode membrane based on fluorescence enhancement of fluorescein derivatives. Talanta 41(6):969-975.

Zeng, Z. T., Jewsbury, R. A. (2000). Fluorimetric determination of iron using 5-(4methoxyphenylazo)-8-(4-toluenesulfonamido)quinoline. Analyst 125(9):1661-1665.

Zerbinati, O., Aigotti, R., Daniele, P.G. (1994) Analysis of chiral carboxylic acids in wine by highjperformance liquid chromatography with coupled UV and circular dichroism detection. J. Chromatogr. A 671(1-2):281-285.

Zhang, W. (1990). Spectrophotometric determination of ethanol in wine with 3',3",5',5"tetrabromophenophthalein ethyl ester potassium. Lihua Jianyan Huaxue Fence 26(6):370-371.

Zhang, W. (1990). Spectrophotometric determination of ethanol in wine with 3',3",5',5"tetrabromophenophthalein ethyl ester potassium. Lihua Jianyan Huaxue Fence 1990,26(6):370-371.

Zhao, J., Buck, R. P. (1991). All-solid-state amperometric ethanol sensor. Biosens. Bioelectron. 6(8):681-687.

Zhi, Z., Ríos, A., Valcárcel, M. (1995). Direct determination of free sulphur dioxide in wine and dried apple samples by using a gas generating and purging device coupled to a continuous flow (injection) system. Analyst 120(7):2013-2018.

Zhou, H., Liu, H., Li, Q.S., Zhao, H.J., Li, W. (1993). Alcohol enzyme electrode. FenxiНиахие21(12):1471.

Zhu, Y., Zhang, X. D., Niu, W. J. (1997) Simultaneous determination of carbohydrates and organic acids in beer and wine by ion chromatography. Mikrochimica Acta 127:189194. 


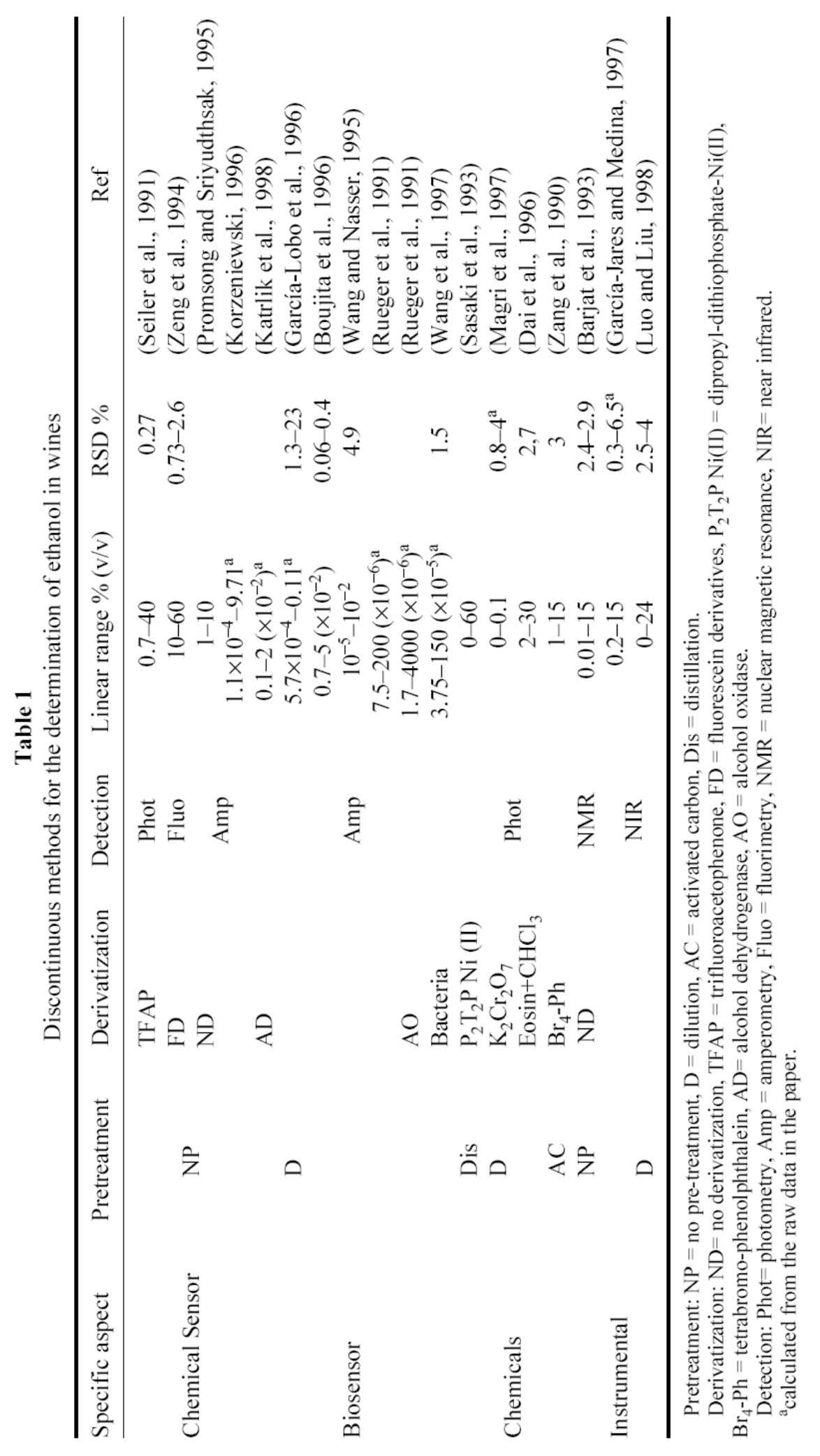





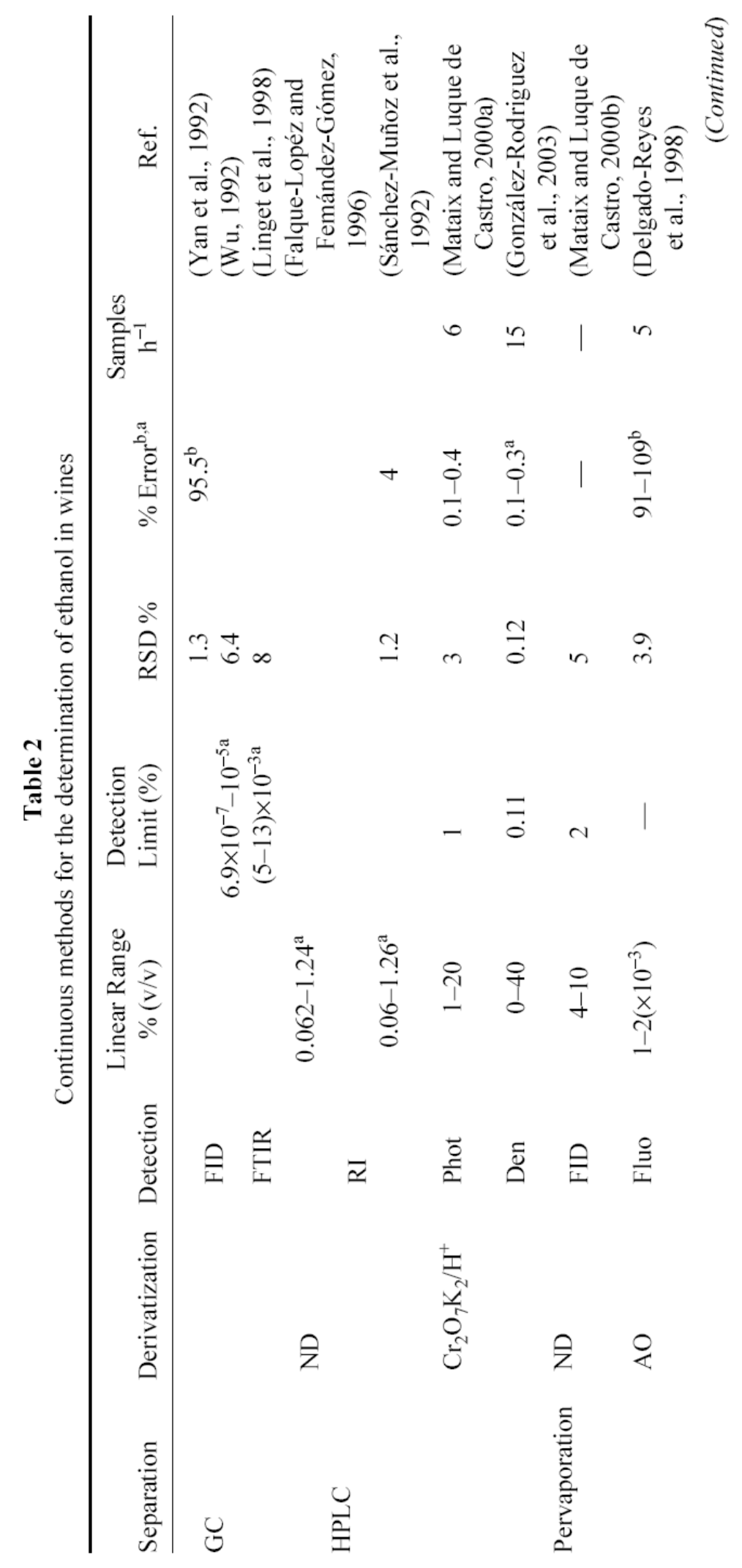





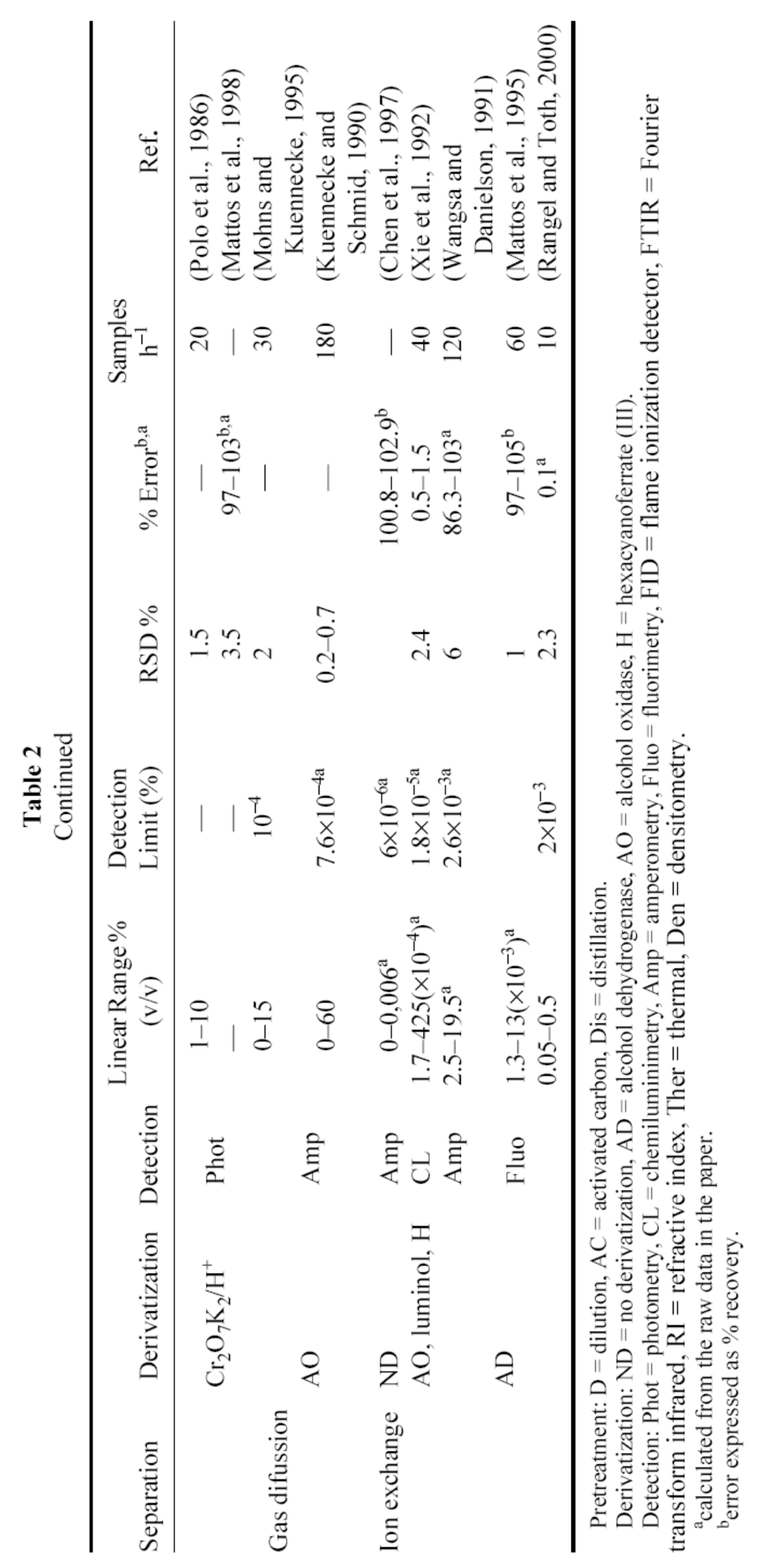




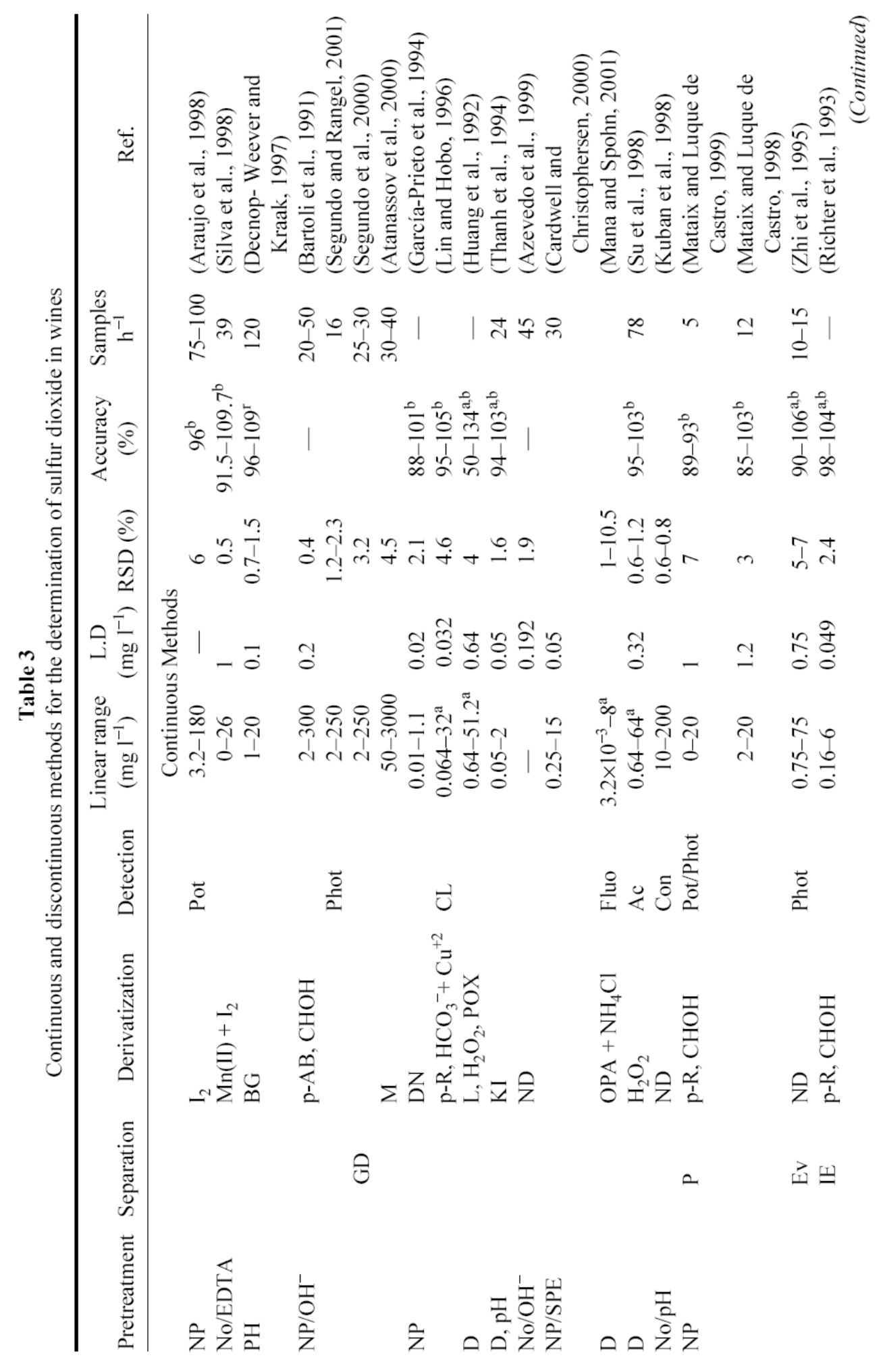





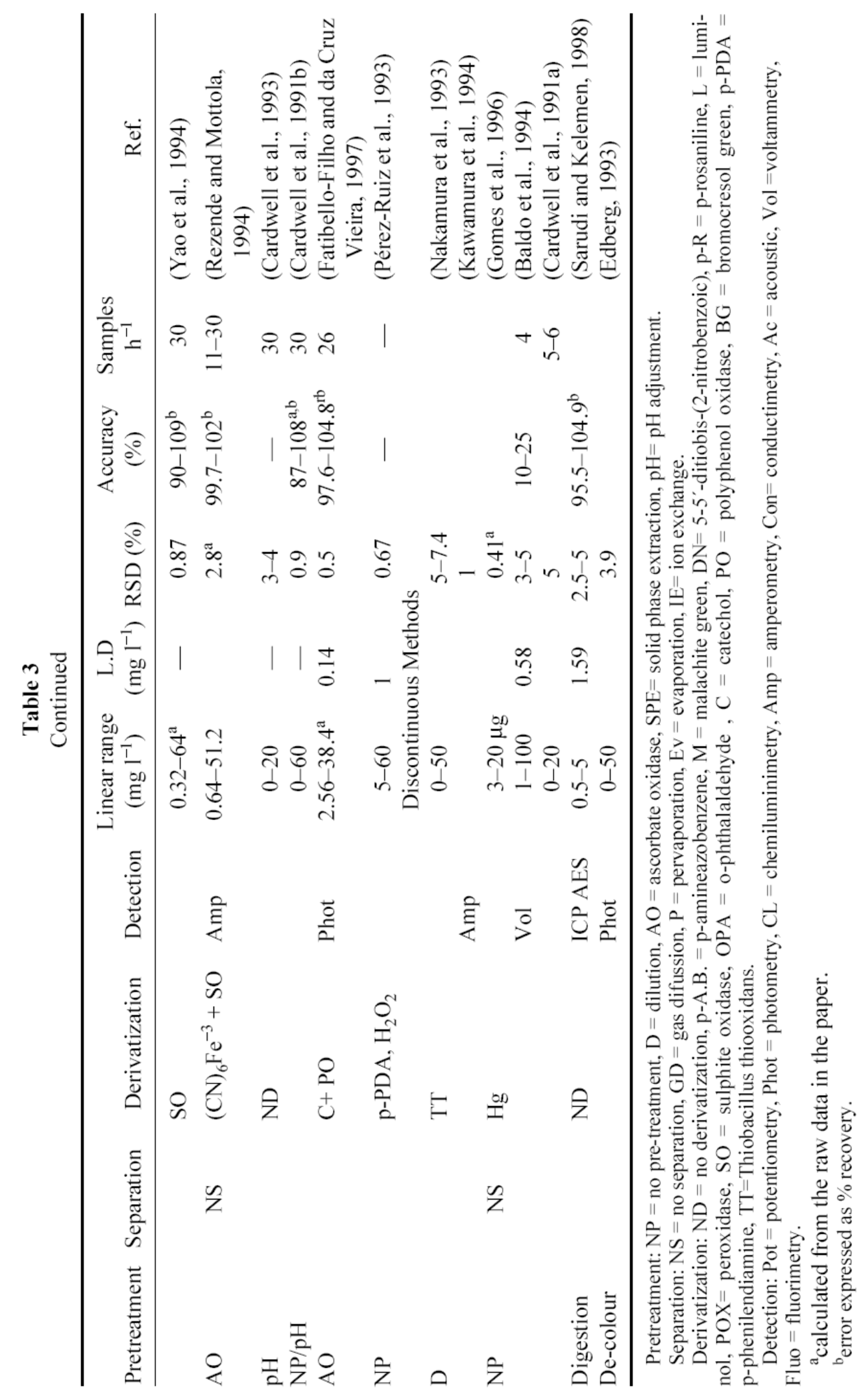





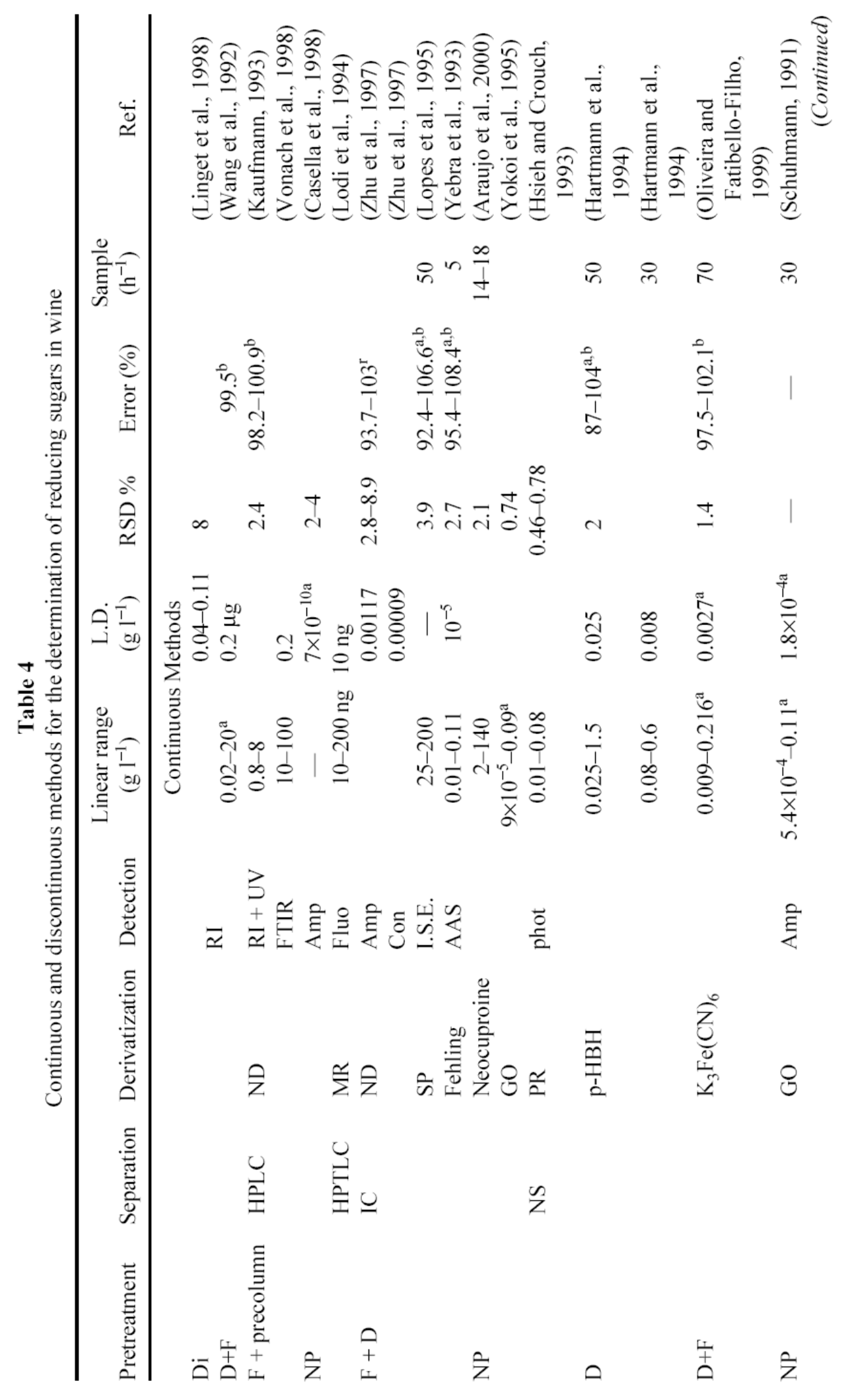





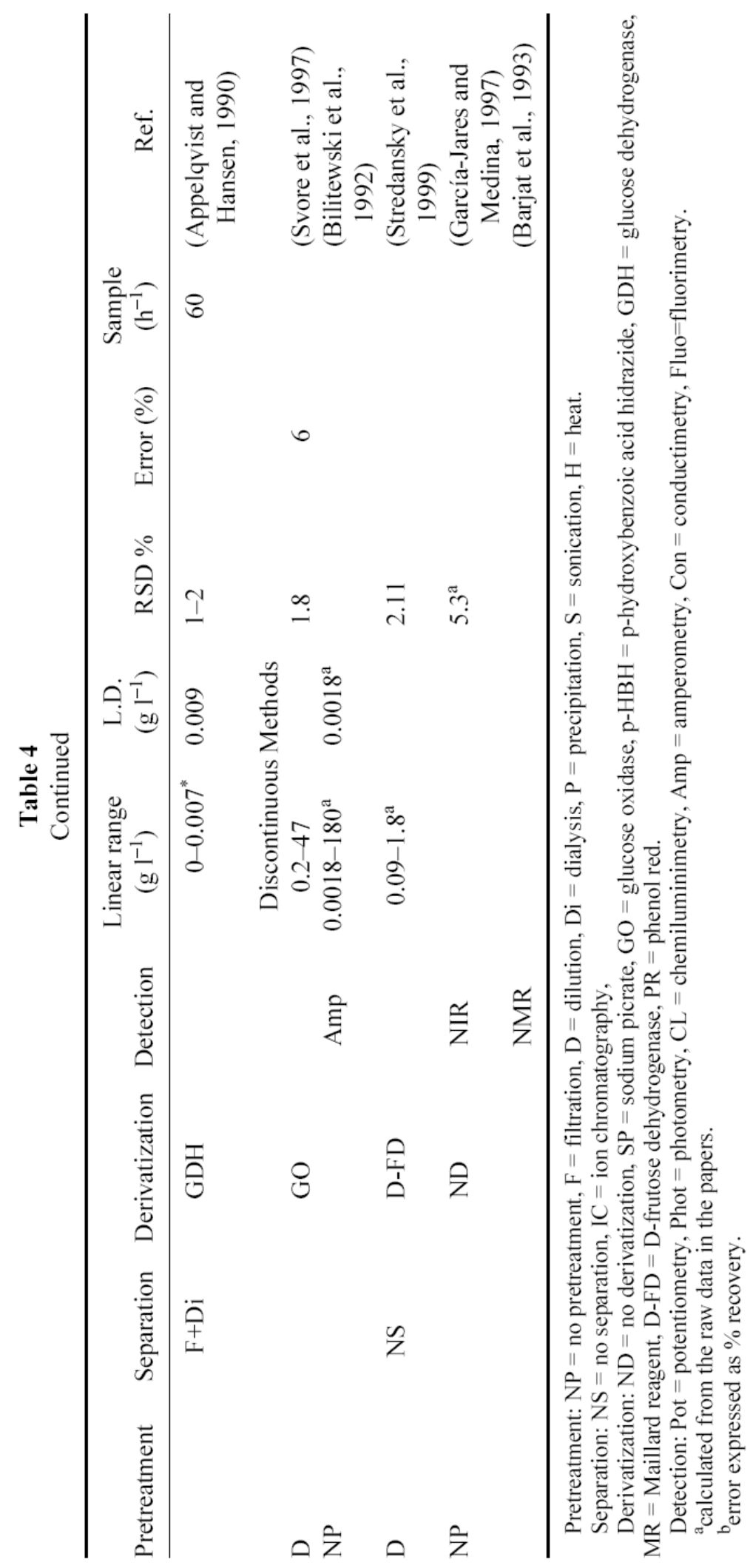





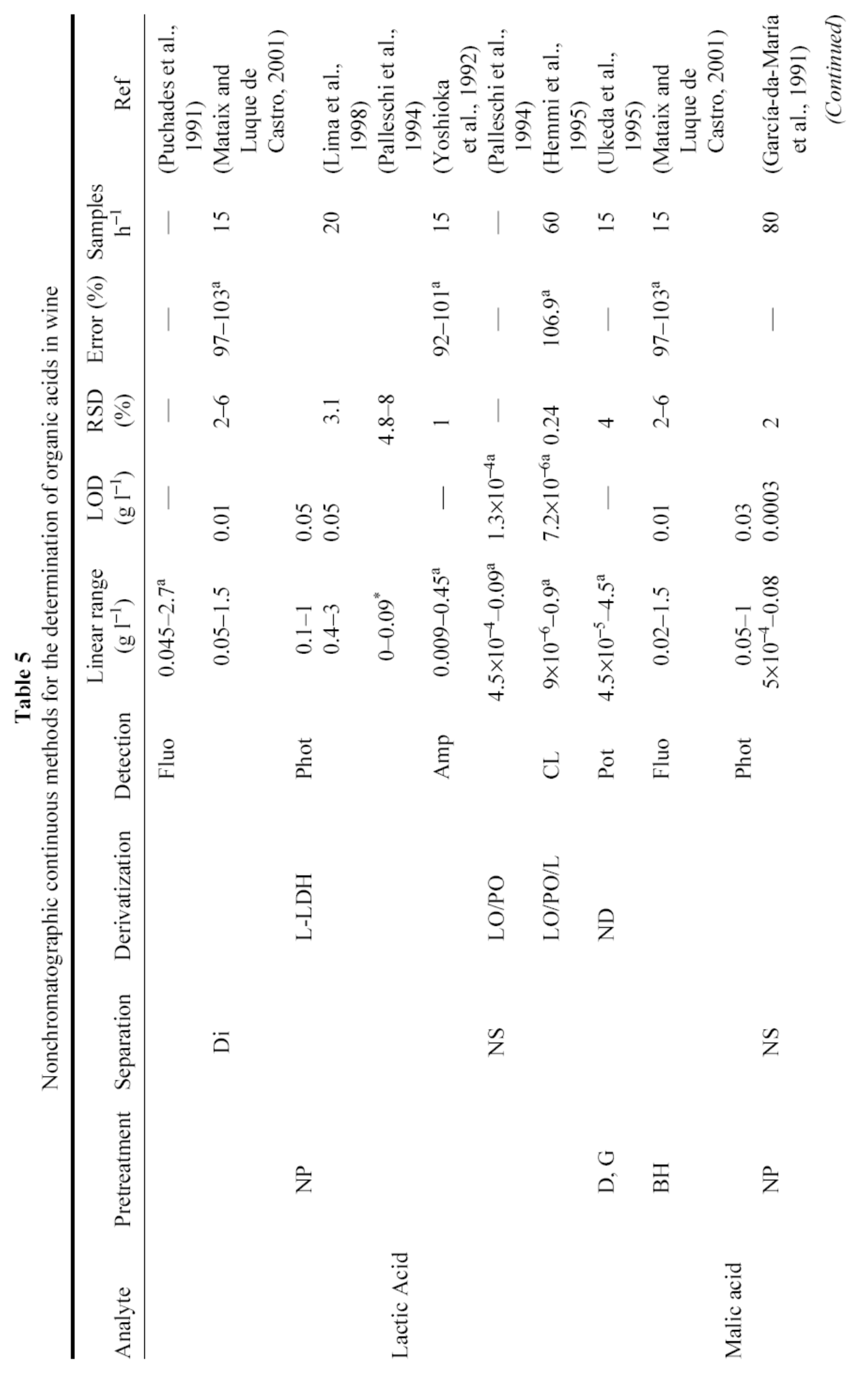




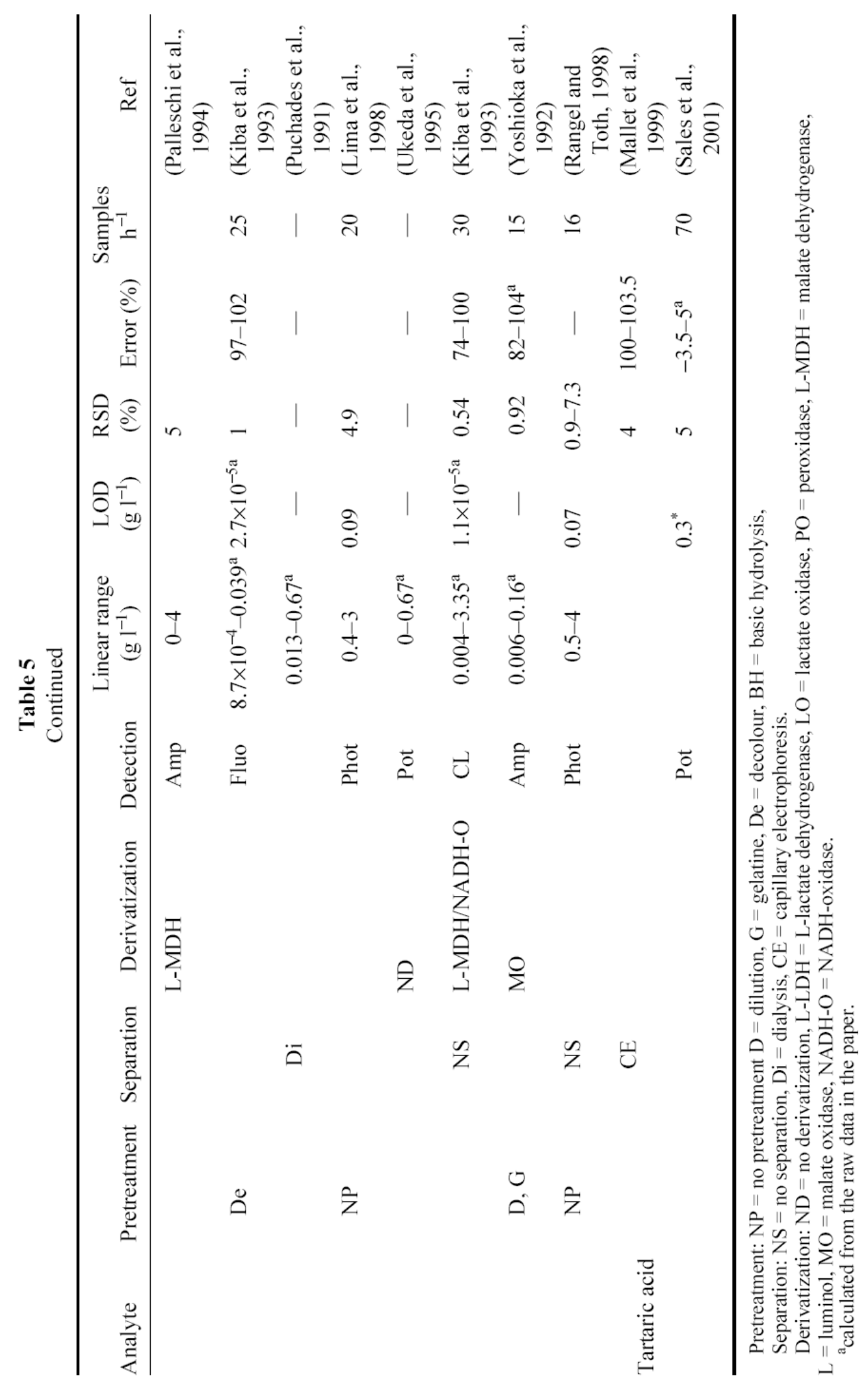





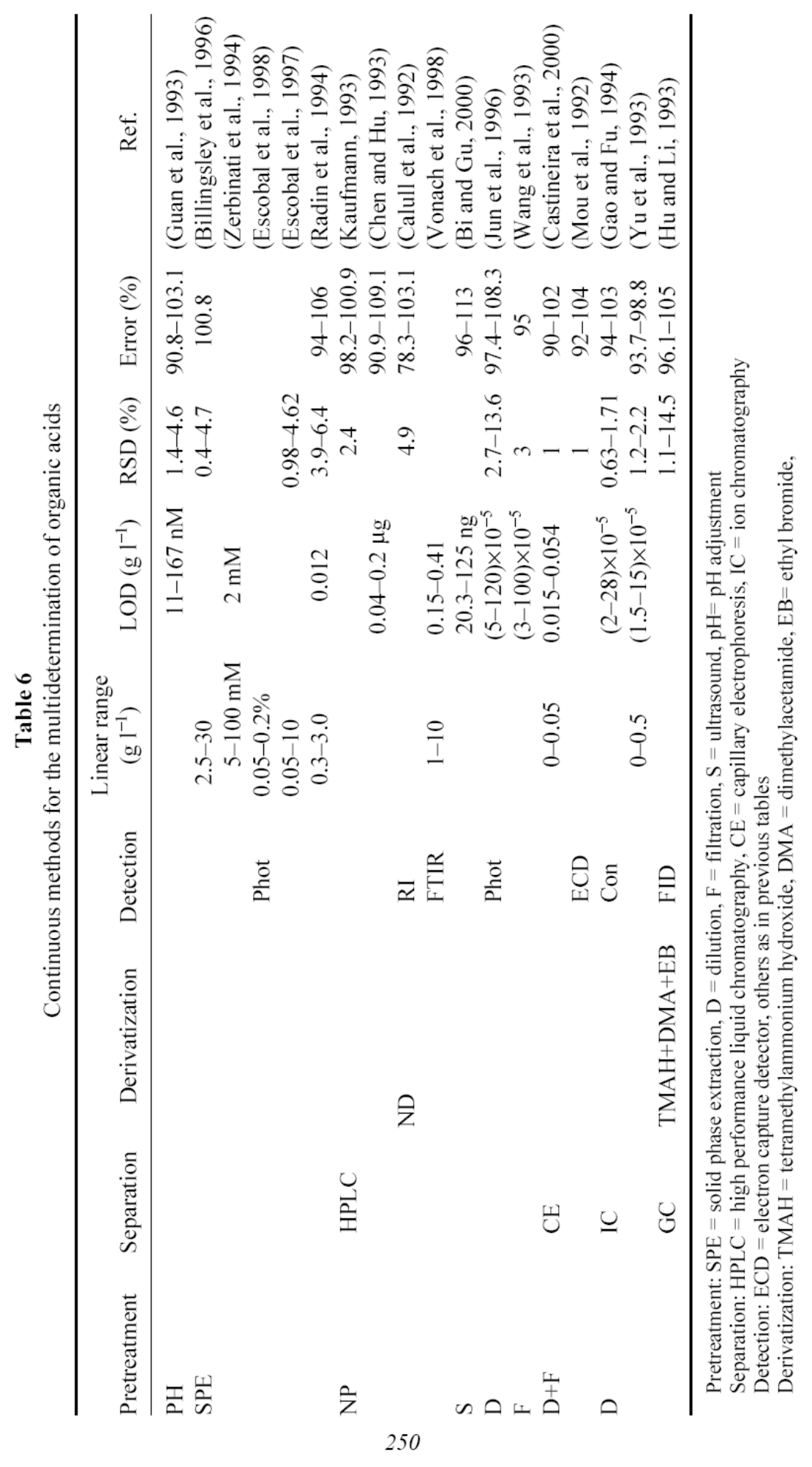


